OPEN ACCESS

Edited by:

Ralf Jockers,

Université de Paris, France

Reviewed by:

Vincent Goffin

Université Paris Descartes, France

Roman L. Bogorad,

Puretech Health, Inc., United States

*Correspondence:

Ger J. Strous

gstrous@umcutrecht.nl;

ger.strous@biminibiotech.nl

Jan A. Mol

j.a.mol@uu.nl

${ }^{\dagger}$ Present addresses:

Ana Da Silva Almeida,

Biogen, Cambridge,

MA, United States

Joyce Putters,

Department of Life, Environment,

and Health, Dutch

Research Council (NWO)

The Hague, Netherlands

Magdalena Sedek,

Merck Chemicals B.V.

Amsterdam, Netherlands

Johan A. Slotman,

Optical Imaging Centre, Erasmus

Medical Center Rotterdam,

Rotterdam, Netherlands

Tobias Nespital,

Biological Mechanisms of Ageing, Max-Planck Institute for Biology of

Ageing, Cologne, Germany

Gerco C. Hassink

Clinical Neurophysiology, Technical

Medical Centre, University of Twente,

Enschede, Netherlands

Specialty section:

This article was submitted to Cellular Endocrinology, a section of the journal

Frontiers in Endocrinology

Received: 21 August 2020

Accepted: 14 October 2020

Published: 18 November 2020

\section{Growth Hormone Receptor Regulation in Cancer and Chronic Diseases}

\author{
Ger J. Strous ${ }^{1,2^{*}}$, Ana Da Silva Almeida ${ }^{1 \dagger}$, Joyce Putters ${ }^{1 \dagger}$, Julia Schantl ${ }^{1}$, \\ Magdalena Sedek ${ }^{1 \dagger}$, Johan A. Slotman ${ }^{1+}$, Tobias Nespital ${ }^{1 \dagger}$, Gerco C. Hassink ${ }^{1 \dagger}$ \\ and Jan A. Mol ${ }^{3 *}$ \\ ${ }^{1}$ Department of Cell Biology, Centre for Molecular Medicine, University Medical Centre Utrecht, Utrecht, Netherlands,
${ }^{2}$ BIMINI Biotech B.V., Leiden, Netherlands, ${ }^{3}$ Department of Clinical Sciences of Companion Animals, Faculty of Veterinary
Medicine, Utrecht University, Utrecht, Netherlands
}

The GHR signaling pathway plays important roles in growth, metabolism, cell cycle control, immunity, homeostatic processes, and chemoresistance via both the JAK/STAT and the SRC pathways. Dysregulation of GHR signaling is associated with various diseases and chronic conditions such as acromegaly, cancer, aging, metabolic disease, fibroses, inflammation and autoimmunity. Numerous studies entailing the GHR signaling pathway have been conducted for various cancers. Diverse factors mediate the up- or down-regulation of GHR signaling through post-translational modifications. Of the numerous modifications, ubiquitination and deubiquitination are prominent events. Ubiquitination by E3 ligase attaches ubiquitins to target proteins and induces proteasomal degradation or starts the sequence of events that leads to endocytosis and lysosomal degradation. In this review, we discuss the role of first line effectors that act directly on the GHR at the cell surface including ADAM17, JAK2, SRC family member Lyn, Ubc13/CHIP, proteasome, $\beta$ TrCP, CK2, STAT5b, and SOCS2. Activity of all, except JAK2, Lyn and STAT5b, counteract GHR signaling. Loss of their function increases the $\mathrm{GH}$-induced signaling in favor of aging and certain chronic diseases, exemplified by increased lung cancer risk in case of a mutation in the SOCS2-GHR interaction site. Insight in their roles in GHR signaling can be applied for cancer and other therapeutic strategies.

Keywords: aging, cancer, ubiquitin, endocytosis, GH/IGF-1 axis, GH sensitivity

\section{INTRODUCTION}

In 1989 with a background of posttranslational modifications and intracellular transport of membrane glycoproteins our lab decided to focus on studying the role of ubiquitination in membrane trafficking. Knowledge on the role of ubiquitination as a major regulator of cell functions had just started to emerge (1). To address the question of whether ubiquitination and membrane trafficking are connected processes, we sought a model membrane protein to focus on. Some evidence suggested that the growth hormone receptor (GHR), isolated from rabbit liver, is 
ubiquitinated (2). We choose this as our model and very soon, it became clear that the two fields were indeed connected (3). Now, we know that both the ubiquitin system and the GHR are crucially important for the regulation of cellular life and metabolism. The state-of-the-art of both fields has been described in excellent recent reviews (4-11). In this review we will connect both systems.

Loss of the GHR is not lethal, but results in sub-optimal health, short stature, decreased bone mineral density, decreased muscle strength, thin skin and hair, increased adiposity, and hepatic steatosis. Interestingly, people with non-functional GH signaling have very low plasma insulin growth factor 1 (IGF-1) concentrations, are highly resistant to cancer and diabetes type 2 and seem to have a slow cognitive decline $(12,13)$. GHR, whose function is more a modulator of cellular processes, may deteriorate healthy aging and act as an important stimulator of carcinogenesis. Our focus will therefore be on the mechanisms involved in the regulation of this important receptor, wherein ubiquitination and phosphorylation enzymes play major parts, and on the impact of these in health and disease.

\section{THE GROWTH HORMONE RECEPTOR}

\section{The Prototype Cytokine Receptor}

GHR is a single membrane spanning protein of 638 amino acids, isolated for the first time from rabbit liver (14). Cloning from several species revealed a strong sequence homology (15). The human GHR is composed by 9 exons (16) encoding a cleavable amino acid signal peptide of 18 (exon 2), an extracellular domain of 246 (exon 3 to 7), a transmembrane domain of 24 (exon 8), and an intracellular domain of 350 residues (exon 9 and 10). GHR belongs to the class 1 superfamily of cytokine receptors, which includes 27 ligands and 34 human type I cytokine receptors (17). The GHR was the first member of the family to be characterized (2) and is expressed in most cells of the human body.

The class 1 cytokine receptors share many features. In the extracellular domain they contain conserved cysteine residues and a WSxWS motif (18). In the case of GHR, this motif is different, although homologous, YGEFS. Alteration of the sequence disrupts ligand binding and receptor signaling (19). Despite the limited amino acid homology, the structures of GHR, EPOR and PRLR are similar, consisting of two fibronectin- (FN) type 3 domains ( $\beta$-sandwich composed of seven $\beta$ strands). In GHR the N-terminal domain is composed of amino acids 19-141 and the C-terminal composed of amino acids 146-264, separated by a four-amino acid hinge region (20). The GHR extracellular domain contains 3 disulfide bridges, formed by 6 of its 7 cysteine residues (Figure 1) (23). The intracellular domain contains two conserved membrane-proximal conserved sequences, referred to as box1 and box2, equivalent to the UbE/TPR motif, with functions in JAK2 binding and GHR endocytosis, respectively. Additionally, a conserved DSGxxS degradation motif is present downstream of box2, whose function is explained later in this review.

\section{GHR Life Cycle}

While being translated on ribosomes, GHR is inserted in the endoplasmic reticulum (ER) membrane due the presence of the signal peptide (Figure 2). In the ER, the disulfide bonds are formed and GHR dimerizes (29). GHR is glycosylated with high mannose oligosaccharides important for the process of quality control in the ER. When correctly folded, higher order (presumably tetrameric) complexes assemble, and GHR continues its route in to the Golgi apparatus (27). In the Golgi, the high mannose oligosaccharides of GHR are processed into complex oligosaccharides.

In 2003, we identified both SGTA and BAG6 as binding partners for the GHR $(30,31)$. The binding depends on an intact UbE/TPR motif, similar as for CHIP and $\beta$ TrCP. Also pentatricopeptide motif-containing proteins like LRP130 were identified (30). The binding was lost if F345 was mutated. Bag6/ Bat3 localized to the nucleus, the Golgi complex and to mitochondria. Inhibition of protein synthesis as well as UVtreatment resulted in a reduction of Bag6 to mitochondria. According to current insight Bag6 can bind to both precursor and mature GHR via SGTA and Ubl4a (32-34). Silencing of UBL4 had no effect on GHR function at the cell surface and its endocytosis (35). Most likely the SGTA/Bag6 complex plays a role in GHR dimerization, and multimerization at the endoplasmic reticulum and in the Golgi complex $(27,36)$.

After this step, the GHRs traffic to the cell surface (Figure 2). Unlike most growth factor receptors, the GHR is continuously synthesized and degraded with a half-life of 30-60 min (37-39). GHR is constitutively endocytosed independently of GH binding $(39,40)$. GH binding at the cell surface initiates signaling, and accelerates endocytosis of the GH-GHR complex $(41,42)$. GHR is sorted into the multivesicular bodies (MVB), and eventually degraded in the lysosome (43). Additionally, when at the cell surface, GHRs can be cleaved by the metalloprotease tumor necrosis factor- $\alpha$-converting enzyme (TACE, ADAM17), a process called shedding $(44,45)$. The cleaved extracellular domain circulates in the blood and is referred to as growth hormone binding protein (GHBP); the intracellular part is endocytosed and degraded. GHBP levels in the blood have been used as an indication of the amounts of GHR in the cells (46). When GH is bound to GHR or if a tri-peptide (E260-D262) is deleted or mutated, shedding is inhibited $(39,47,48)$. In the bloodstream, GHBP may antagonize GH actions by competing for its binding with GHR at the cell surface (49). Alternatively, the GH-GHBP complex may increase the bioavailability of GH in the circulation. Another function of the shedding process is downregulation of the responsiveness of the cells to GH. The availability for $\mathrm{GH}$ at the cells surface is determined by the rate of GHR endocytosis (75\%), the rate of shedding (10\%), and other (unknown) mechanisms (15\%) (50). Control of GHR endocytosis is crucially important. The high turnover rate allows cells to quickly respond to stresses and changing metabolic conditions.

Both GHR and its kinase, JAK2, can translocate to the nucleus. The JAK2 transport can be facilitated by the sumoylation machinery (24).Under certain conditions at defined cell cycle- regulated times in proliferative cells, activated GHR escapes via the cytoplasm to the nucleus by the importin- $\alpha / \beta$ mediated classical import pathway. 


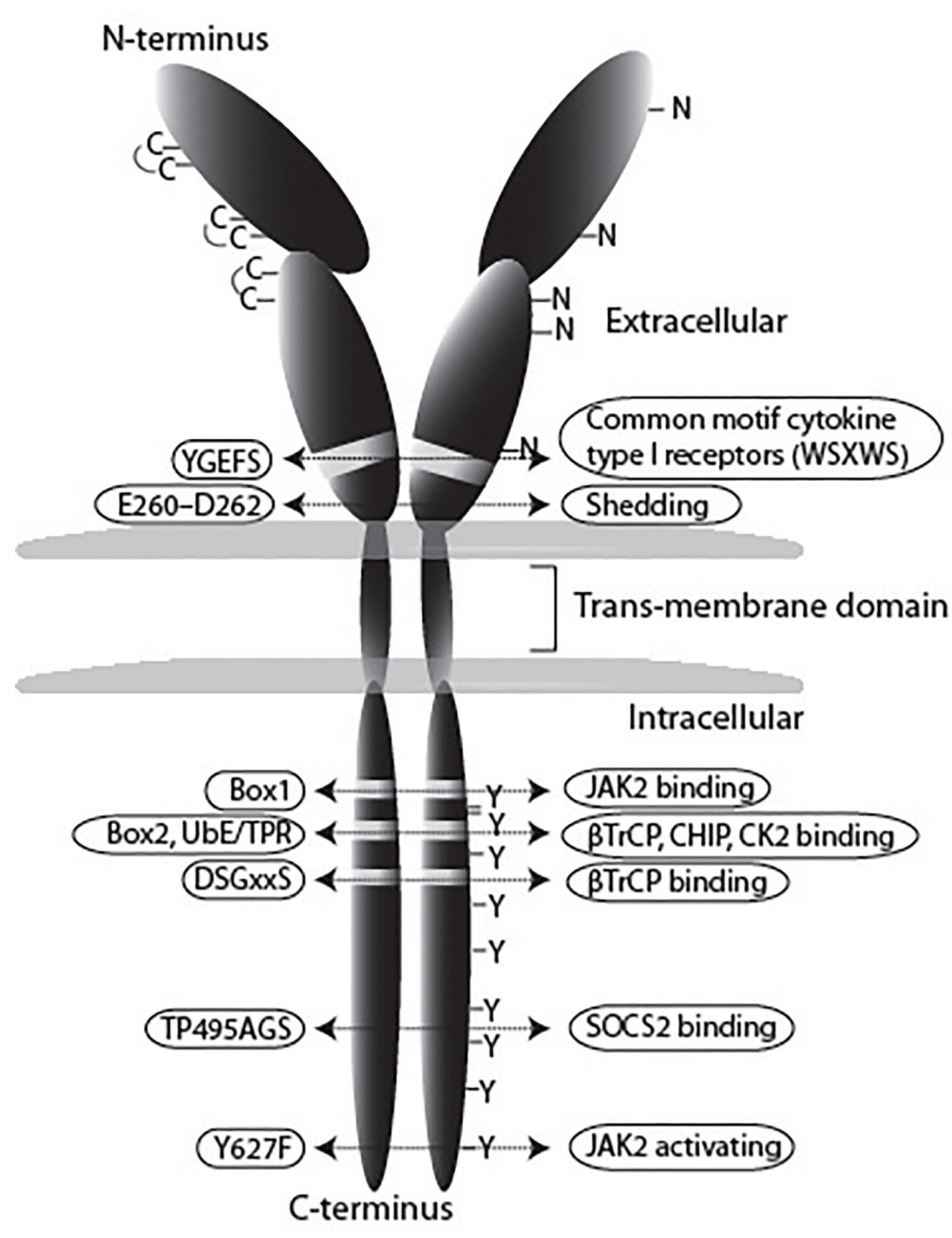

FIGURE 1 | Schematic representation of the GHR. In this review we use the notation of the human GHR protein (GenBank: AAA52555). The GHR consists of an extracellular domain of 246 amino acids, a transmembrane domain (TMD) of 24 residues, and a cytoplasmic region of 350 amino acids. The extracellular domain contains 5 potential glycosylation sites $(\mathrm{N})$, and seven cysteine residues, from which 6 form disulfide bonds. The YGEFS domain is located at the C-terminal part of the extracellular domain. The intracellular domain contains 9 tyrosine residues that can be phosphorylated upon receptor activation by GH. E260-D262 are involved in ADAM17 shedding activity, Box1 is responsible for JAK2 binding, the membrane-proximal 150 amino acids contain the SRC (Lyn) binding site; UbE/TPR and DSGXxS are for GHR internalization and degradation, TP495AG serves as SOCS2 binding site (21), and Y627F causes constitutive JAK2 activation (22).

This process requires interaction with the nuclear localization signal-containing protein Co-activator activator (CoAA). Through its N-terminal domain nuclear GHR can act as a transcriptional activator in conjunction with CoAA to initiate transcription of a subset of target genes to regulate cell cycle progression. Most likely, the nuclear GHR together with CoAA increases the proliferative action of $\mathrm{GH}(25,26)$. Details as whether dimeric, phosphorylated $\mathrm{GHR}$, or whether JAK2, or GH are needed, are currently lacking.

\section{GROWTH HORMONE PHYSIOLOGY}

\section{GH Family and Structure}

Growth Hormone $(\mathrm{GH})$, also known as somatotropin or somatotropic hormone, is a peptide hormone produced in the anterior pituitary gland which promotes cell division, regeneration and growth (6). Phylogenetically, GH is an ancestral hormone that has been found in the pituitary of primitive vertebrates, such as the jawless sea lamprey fish (51). In primates, GH is part of a family of highly similar genes consisting of $\mathrm{GH} 1$ which is mainly expressed in the pituitary, a placental GH variant gene known as $\mathrm{GH} 2$, and three placental lactogens also known as chorionic somatomammotropin genes (CSH1 and CSH2) and chorionic somatomammotropin-like gene (CSHL1). Several GH isoforms have been identified, but in humans the majority of the circulating $\mathrm{GH}$ is the $22,000 \mathrm{GH} 1$ form from the pituitary gland $(52,53)$. Some extra-pituitary tissues (e.g. neural, immune, reproductive, digestive, respiratory systems among others) have also been found to produce GH (54). Thus, GH and also PRL expression is widely spread in many tissues throughout the body where it has autocrine or paracrine functions and may play a 


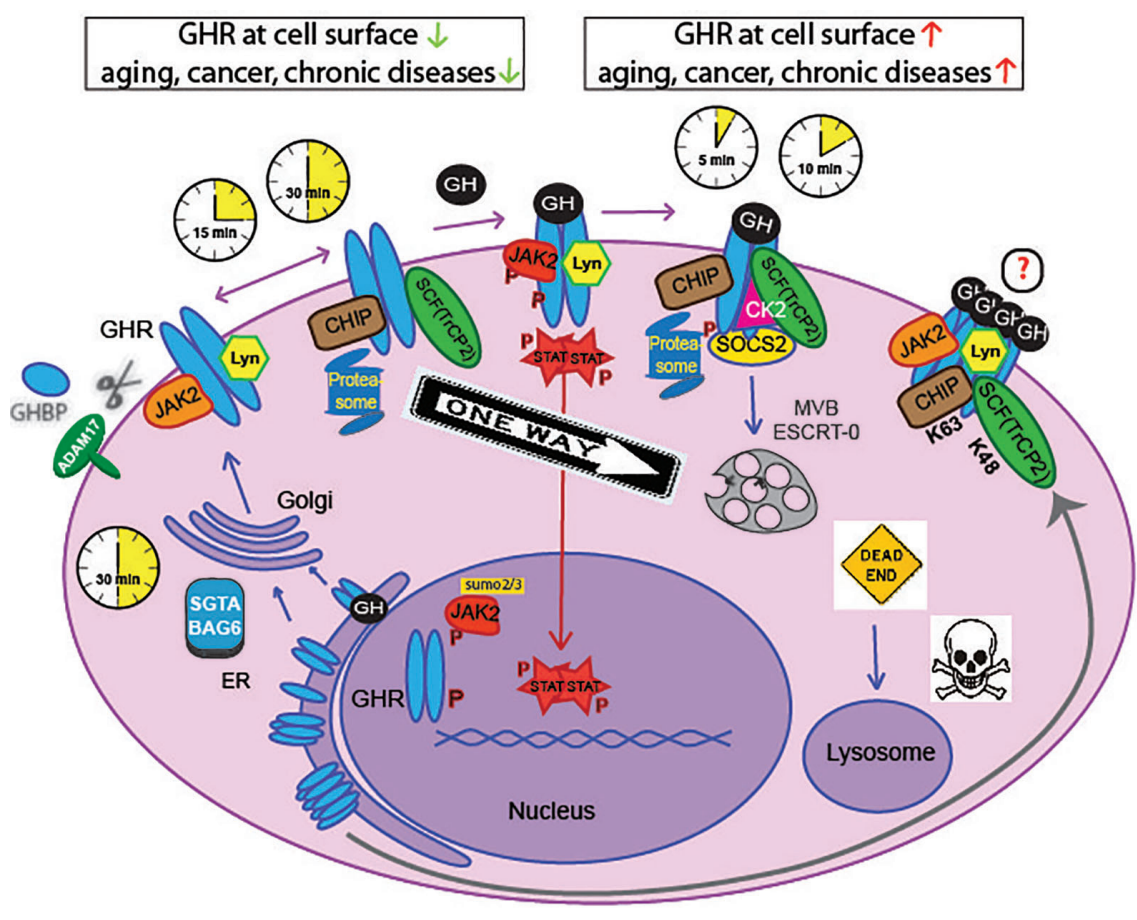

It's all about timing

FIGURE 2 | Life cycle of the GHR. GHR is synthesized in the endoplasmic-reticulum (ER) where it undergoes N-glycosylation and dimerization. The small glutaminerich tetratricopeptide repeat-containing protein SGTA together with Large proline-rich protein BAG6 (or BCL2-associated athanogene 6), SGTA/BAG6, probably act as chaperone in GHR complex formation toward the Golgi complex. After complex glycosylation in the Golgi the GHR arrives at the plasma membrane within 30 min. With no GH present, the GHR endocytoses via coated pits catalyzed by $\beta \operatorname{TrCP}$ (on DSGxxS motif, Figure 1), Ubc13/CHIP, and the proteasome, within 30 min after arrival. Alternatively, the GH binding domain (GHBP) is shedded into the blood by the action of ADAM17. If GH binds to the GHR, signal transduction is initiated via JAK2, Lyn, and CK2; in addition, SOCS2 is recruited to the degron sequence TP ${ }^{495}$ AGS, downstream of the STAT5b-interacting pY487. The activated GHR uses the same ubiquitination machinery but a different motif (UbE/TPR) for $\beta$ TrCP binding and endocytosis. This shortens the residence time to 5-10 min, as explained below and in Figure 5. The endocytosed GHRs are then transported through endosomes, selected by the ESCRT-0 complexes at the multivesicular bodies (MVB) and degraded in the lysosomes. The CK2 involvement is hypothetical. Upon GH binding, JAK2 and Lyn phosphorylate downstream effectors. Phosphorylated STATs translocate to the nucleus and activate many genes. Both GHRs and JAK2 can be translocated to the nucleus (24-26). High-order functional GH-GHR complexes may occur that upon activation are phosphorylated and act as signaling platforms $(27,28)$. If GH and GHR are expressed in the same cell, they bind in the ER and the signaling starts from the Golgi complex.

role in various diseases. Autocrine GH may have an even greater role in cancer development than endocrine GH (55). In mammary tissue GH1 expression has been found to be regulated by progesterone (56-58). GH belongs to the same family as prolactin (59), and in primates GH binds also to the PRLR, which presumably implicates all PRLR-mediated actions including mammary gland differentiation and lactation. Two disulfide bounds are necessary for its biological activity (60). Before closure of the growth plates, recombinant $\mathrm{GH}$ can be given to promote growth in children with short statue (61).

\section{GH Secretion and Availability}

$\mathrm{GH}$ is released from the somatotropic cells in the anterior pituitary in a pulsatile manner (Figure 3). In man, $\mathrm{GH}$ is secreted episodically with a major surge at the onset of the slow-wave sleep, and less pronounced secretory episodes a few hours after meals (62-64). The pulsatility of GH secretion has a major impact on the pattern of $\mathrm{GH}$-induced hepatic gene expression (65-67). Sexually-dimorphic patterns of genes manifest themselves in the liver through the pulsatile nuclear and DNA occupancy of STAT5b in males, while In females a more continuous pattern leads to dramatic differences in gene expression (68-70). Pulses are regulated primarily by the interplay of hypothalamic hormones: a stimulatory $\mathrm{GH}$ releasing hormone $(\mathrm{GHRH})$ and an inhibitory hormone, somatostatin (SS). These factors act via their respective receptors, expressed at the cell surface of the somatotropic cells. In addition, other peptides, called secretagogues (GHS), were identified to regulate GH secretion, such as GH releasing peptides (GHRP) originating from the brain (71), and Ghrelin, produced by stomach tissue (72). Additionally, insulin-like growth factors (IGFs), of which the transcription depends on $\mathrm{GH} / \mathrm{STAT5b}$ signaling, are able to inhibit $\mathrm{GH}$ release in a negative feedback loop (73). Expression and release of GH are mainly regulated by the transcription factor Pit-1, which has additional functions in the differentiation and maintenance of 
somatotropic cells $(74,75)$. GH secretion is also affected by other factors such as physical stress, body composition, metabolic status and others (Figure 3). For instance, during fasting and certain conditions of physical stress, $\mathrm{GH}$ secretion is increased, and excess of glucose or lipid intermediates inhibits GH release in healthy man $(63,76-78)$. After maximal GH secretion at puberty (79), adulthood is associated with its gradual decline (80). Besides the tight regulation of $\mathrm{GH}$ secretion, the availability of $\mathrm{GH}$ is also influenced by its clearance by the kidneys and by internalization through its receptor. During pregnancy, the pulsatile $\mathrm{GH}$ secretion is completely abolished due to the placental GH2 secretion which evokes elevated plasma IGF-1 concentrations inhibiting pituitary GH1 release by feedback inhibition. Because of this, insulin-resistance may develop eventually leading to pregnancy diabetes (81).

\section{GHR ACTIVATION, SIGNALING, AND DESENSITIZATION}

$\mathrm{GH}$ signaling not only depends on the amounts of $\mathrm{GH}$ in circulation, but also on the levels of GHR at the cell surface. The responsiveness (sensitivity) of the cells to GH is dynamically regulated, reflecting a balance of receptor endocytosis/ degradation, and transport of newly synthesized receptors to the plasma membrane (50).
If $\mathrm{GH}$ and GHR are synthesized in the same cell, autocrine signaling occurs. Binding and complex formation takes place in the ER, but signaling starts only in the Golgi complex $(27,82)$. As it is a continuous process, the kinetics of downstream signaling certainly differ from the endocrine mode. While for the latter, JAK2-induced phosphorylation is rapidly counteracted by SOCS activity and endocytosis, the autocrine signaling occurs continuously from inside and there is no information about the exact role of the different factors discussed in this review. Most likely, cells that synthesize GH, already carry GH-GHR complexes at the cell surface and react differently upon $\mathrm{GH}$ from outside the cell.

\section{Receptor Activation Mechanisms}

The class 1 cytokine receptors do not have intrinsic kinase activity (83). This role is mediated by JAK2 and the SRC kinase family member, Lyn, that associate with sequences in the cytosolic tail: box1 for JAK2 (84), and the membrane proximal 150 residues of the cytoplasmic domain for Lyn (85). In this review we choose Lyn as a member of the SRC family, but also c-Src and Fyn may be involved (86).

The first step in GH action is its binding to the GHR. The crystal structure of the extracellular domain of GHR bound to $\mathrm{GH}$ revealed that one $\mathrm{GH}$ molecule binds with two asymmetric binding sites two molecules of GHR (20) (Figure 4). For a long time, it was thought that GH binding to one GHR monomer at the plasma membrane recruits the second monomer of GHR to

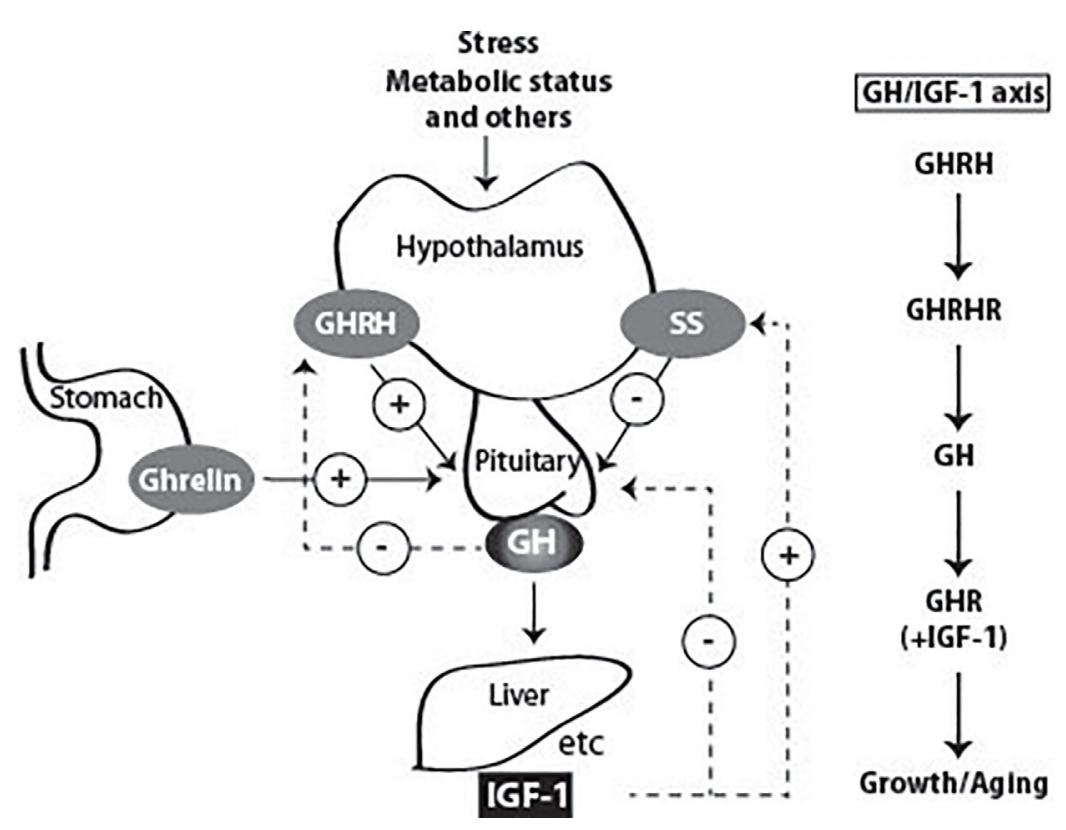

FIGURE 3 | Factors that stimulate and suppress GH secretion under physiological conditions. Several factors influence GH secretion including stress, nutrition, and exercise among others. However, two factors are the main regulators: GH releasing Hormone (GHRH) and somatostatin (SS), which stimulate and inhibit GH secretion, respectively. Ghrelin produced in the stomach also stimulates GH release. GH stimulates the synthesis of IGF-1 by the liver, and in other peripheral tissues. Both GH and IGF-1 are involved in negative feedback loops. High GH levels inhibit its own secretion by inhibiting the release of GHRH. High blood levels of IGF-1 lead to decreased secretion of GH by direct suppression in the pituitary and by stimulating the release of SS. 


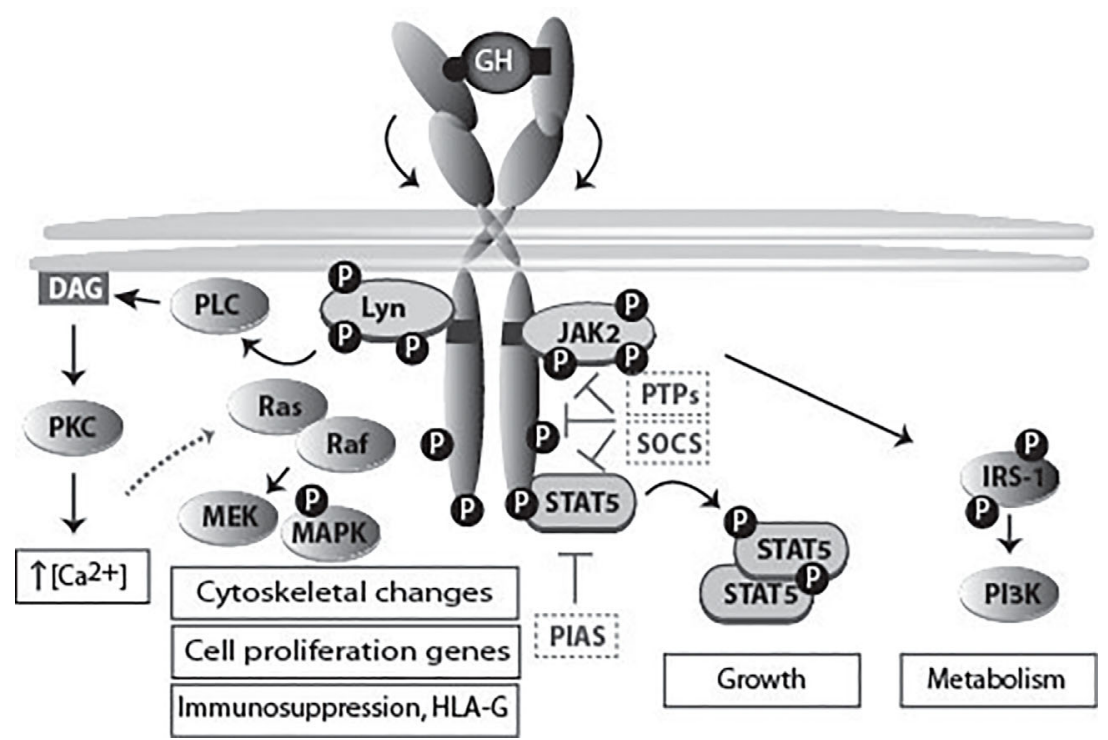

FIGURE 4 | GHR activation and signaling. The binding of the two asymmetric binding sites of one GH molecule to the GHR dimer causes its rotation and subsequent activation of downstream signaling pathways, and ultimately specific gene transcription. The activation of different signaling pathways accounts for the multitude of GH functions. JAK2 binds to box1, while the SRC family member (Lyn) binding is to the membrane proximal 150 residues (85). Lyn activates PLC $\gamma$, which leads to an increase in the cytoplasmic calcium ion concentration. This process results in RAS activation and initiation of the ERK1/2 signaling pathway. In the scheme also molecules involved in signal termination (PTPS, SOCS and PIAS) are indicated. In Figure $\mathbf{7}$ the physiology and pathophysiology are further detailed.

its second binding site. JAK2 activation was proposed to occur due to GHR dimerization itself. However, subsequent studies disproved this model. Studies by Gent and collaborators showed that GHR dimerizes in the ER, independently of GH, and travels to the cell surface as a pre-formed dimer (29). Subsequently, work by the group of Waters suggested that a change in conformation, induced by GH, rather than GHR dimerization, is responsible for GHR activation. In this study, the comparison of the crystal structure of the extracellular domain of GHR alone and the previous structure of $\mathrm{GH}$-bound GHR revealed differences in conformation (87). Based on this knowledge, the current model for GHR activation proposes that GH binding to the GHR dimer causes a change in conformation in the extracellular binding domain This structural change causes the receptor transmembrane domain to change from a parallel to a left-handed crossover interaction. This structural transition leads to a separation of the intracellular domain, at least to the Box1Box2 motif, dissociates the JAK2 kinase/pseudokinase transinteraction and brings the JAK2 kinase domains in proximity, allowing trans-phosphorylation and activation (88, 89). As described for many cytokine receptors, high-order functional GH-GHR complexes of 900,000 Mr occur that upon activation are phosphorylated and act as signaling platforms as identified by native polyacrylamide gel electrophoresis $(27,28,90)$.

The phosphorylation of specific tyrosine residues, brought about by JAK2 and Lyn, has extensively been studied as intermediaries for recruiting downstream signaling effectors (91). Herewith in agreement, we confirmed that tyrosine residues 487,534 , and 627 , but not residue 566, are most important for GHR and STAT5b phosphorylation. In addition, we showed that the GHR(Y627F) mutation constitutively (independent of $\mathrm{GH}$ binding) activates JAK2 and downstream effectors (92).

\section{JAK2 Activation}

JAK2 is composed of four major domains: a N-terminal FERM (4.1 protein, ezrin, radixin, and moesin) domain, followed by a SH2 (Src homology 2) domain, pseudokinase and kinase domains. The binding to the boxl of GHR occurs through the FERM domain (93). Normally JAK2 is held in an inactive conformation, where the kinase and pseudokinase domain interact with each other (94). The activation of JAK2 requires that two catalytic domains are brought in close proximity. This was concluded after realizing that often in human leukemia there is oligomerization of JAK2 molecules which renders them constitutively active; this aggregation is due to the occurrence of a genetic fusion between the JAK2 catalytic domain and the oncogenic transcription factor TEL (95). Analysis of other mutation also contributed to the understanding of JAK2 physiology. The mutation V617A, which turns JAK2 into a constitutively active state, is found in patients with myeloproliferative disorders (96). This mutation probably disrupts the inhibitory interaction between the pseudokinase and kinase domain (97). Following mutational analysis, the SH2-pseudokinase domain linker turned out to be important for JAK2 activation (98). JAK2 activation results in the phosphorylation of multiple tyrosines. Several of these have been identified as important in the regulation of JAK2 function. For example, phosphorylation at tyrosine 1,007 is thought to expose the substrate and/or ATP binding sites (99), and phosphorylation of tyrosine 119 is thought to promote JAK2 dissociation from its receptor (100). Phosphorylation of tyrosine 813 appears to enhance JAK2 activity (101), whereas phosphorylation of tyrosine 221 
decreases it (102). The importance of many of the JAK2 tyrosines is related to their roles in recruiting ancillary molecules needed for signaling propagation or signal termination.

Unexpectedly, the JAK/STAT signaling pathway is downregulated at febrile temperatures (103). JAK2 protein levels rapidly decrease in cells exposed to thermal stress, while its synthesis remains normal. The analogy of these findings in a variety of cell lines, as well as in PBMCs isolated from human blood, indicate the universal validity of this effect. Although JAK2 is a stable protein, it is degraded in a ubiquitin-dependent manner via the ubiquitin proteasome pathway (104). The significance of this process was illustrated in mouse 3T3 cells that showed a decreased $\mathrm{GH}$ response at $40^{\circ} \mathrm{C}$. JAK2 underwent aggregation in an irreversible manner. Interestingly, kinaseinactive JAK2 did not show aggregation, although the effect of degradation in the cytoplasm at elevated temperatures was conserved. The findings predict that elevated body temperatures lower the responsiveness of cytokine receptors.

\section{SRC Activation}

For a long time JAK2 has been regarded as the only kinase activated directly via the GHR. However, recent data, indicating that not all the $\mathrm{GH}$ signaling events rely on JAK2, brought controversy to the field. In particular, the activation of Lyn (SRC family kinase member) can occur independently of JAK2. First evidence came from a study by Zhu et al, who showed this by using pharmacological inhibitors and kinase inactive proteins (105). Additional evidence came from Rowlinson and co-workers, who reported that interfering with the GH-induced GHR conformational change affects JAK2 and Lyn activation differently (85). Activation of STAT5b by GH seems to require only JAK2, while activation of the small GTPases RalA, RalB, Rap1 and Rap2 by GH requires both Lyn and JAK2 (105). Lyn activation by GH was shown to activate MAPKs, also referred to as extracellular signalregulated kinase 1 and 2 (ERK1 and ERK2), through the phospholipase $\mathrm{C} \gamma$-Ras pathway, signaling that might promote oncogenesis (85). Genes exclusively regulated by Lyn include genes involved in mRNA transcription and metabolism, including the GHR itself: the basal GHR expression level via Lyn is 4.8-fold higher, comparing GHR Box1-/- vs. GHR-/- (106). GHR signaling via this pathway induces also HLA-G, a powerful immunosuppressive protein for NK cells and macrophages. GHenhanced immunosuppression in tumors might evade immune attack. On the other hand, it might be used to stop excessive inflammation after partial hepatectomy allowing liver regeneration and survival, Figs. 4 and 7 (107). For 3T3-F442A preadipocytes and H4IIE hepatoma cells it has been shown that relative levels of JAK2 and SRC family kinase in any particular cell might determine which kinase is the major signaling element, with JAK2 predominating in most cases (108). Barclay and co-workers showed that targeted mutation in the box1 of GHR in mice, although abrogating JAK2 activation, did not decrease the hepatic activation of MAPK via Lyn (106). The importance of this pathway came from studies with exon 3-deleted GHR, which results in the deletion of 22 amino acids in the extracellular domain of the GHR. Males with this genotype exhibit reduced basal but enhanced ERK signaling after GH stimulation. Exon 3-deleted GHR individuals showed lower serum IGF-1 levels, and were found to be of higher stature with extended lifespan (10 years) (109).

\section{Signaling Pathways of GH}

The main pathways activated by GH are: the signal transducer and activator of transcription (STAT) pathway, the mitogenactivated protein kinase (MAPK) pathway, and the phosphoinositide-3 kinase (PI3K) pathway (Figure 4). The extent by which each pathway is activated depends on the cell types, related to differences in relative expression levels of the components of each pathway.

\section{The STAT Pathway}

STATs are latent transcription factors that upon activation by certain hormones or cytokines undergo tyrosine phosphorylation in the cytoplasm, dimerize via phosphotyrosine-SH2 interactions, and translocate into the nucleus where they activate transcription of specific genes (110). In mammals seven members of STAT have been identified with molecular weights ranging from 95 to 111,000 $\mathrm{Mr}$ (111). GH stimulation creates STATs binding sites in the GHRJAK2 complex. The activation of STAT5b is critical for many of the $\mathrm{GH}$ biological functions, including metabolic changes, body growth and sex-dependent liver gene regulation $(112,113)$. Sex-biased genetic programs in liver metabolism and liver fibrosis are controlled by EZH1 and EZH2 downstream of GH-activated STAT5b (114). STATs 1 and 3 also become activated in response to GH (112), but their importance is still unclear.

STAT5b binds to the promoter elements of the IGF-1 gene, regulating its transcription in a $\mathrm{GH}$-dependent manner (115, 116). A mutation in STAT5b, affecting its GH-induced tyrosine phosphorylation, caused severe growth retardation and immunodeficiency in one patient (117). Since then, more germline STAT5b missense variants with demonstrable dominant-negative effects, associated with short stature and mild immune dysregulation were identified in three unrelated families (118). This reiterates the importance of STAT5b for IGF-1 expression. STAT5b, but not STAT3, requires an intact and tyrosine phosphorylated GHR cytoplasmic tail for full activation (119). The key GHR tyrosines necessary for this event were identified $(120,121)$.

\section{The MAPK Pathway}

The Ras/MAPK, or ERK/MAPK has also been shown to be activated by GH. GHR phosphorylation creates docking sites for Src homology 2 domain-containing transforming protein $\mathrm{C}$ (Shc) (122). Shc gets then phosphorylated by JAK2, and binds growth factor receptor-bound protein 2 (Grb2) which binds Son of Sevenless (SOS), a guanine nucleotide exchange protein. Subsequently, Ras, Raf, mitogen-activated protein kinase/ extracellular-regulated protein kinase (MEK), and ultimately MAPKs are sequentially activated (123). Phosphorylated MAPKs translocate to the nucleus where they transactivate transcription factors, and change gene expression to promote growth differentiation or mitosis. Data suggest that $\mathrm{GH}$ dependent activation of the Ras/MEK/MAPK pathway 
contribute to $\mathrm{GH}$-stimulated c-fos expression through serum response element (SRE). It remains controversial whether and how MAPK activation affects $\mathrm{GH}$-induced proliferation and anti-apoptosis (124). As explained above, the activation of MAPKs may occur in a Lyn-dependent, JAK2 independent way. As STATs are also serine phosphorylated for full activity (125), it was suggested that this is mediated by MAPK pathway (126).

Some evidence suggests that GH signaling via MAPK pathway may engage in cross-talk with signaling pathways induced by other stimuli. Yamauchi and co-workers propose an interesting mechanism by which GH activates MAPK through stimulating the phosphorylation of a Grb2 binding site in the epidermal growth factor (EGF) receptor (127). Additionally, studies by Kim and co-workers show that GH stimulation alters the phosphorylation status of ErbB-2, a tyrosine kinase growth factor receptor member of the EGF receptor family, in a MAPK dependent manner (128). GH has also been described to activate other members of MAPK pathway, namely p38 MAP kinase and c-Jun amino-terminal kinase (JNK) $(129,130)$.

\section{The PI3K Pathway}

$\mathrm{GH}$ has also been shown to stimulate the PI-3K pathway, probably through tyrosyl phosphorylation of the large adaptor proteins, the insulin receptor substrates (IRS). GH stimulates the phosphorylation of IRS-1, -2 , and -3 by JAK2, which leads to their association with multiple signaling molecules including the p85 subunit of PI-3 kinase $(122,131)$. This pathway is shared by the insulin signaling pathway, which may justify the insulin-like effects of acute $\mathrm{GH}$ stimulation under certain conditions, as discussed above. Particularly, activation of PI-3 kinase mediates the GH-induced increase in glucose transport, via induction of translocation of the glucose transporter 4 (GLUT4) to the cell surface (132), and has been suggested to mediate the ability of $\mathrm{GH}$ to stimulate lipid synthesis $(133,134)$. Additionally, PI-3 kinase activation results in AKT activation, which has been implicated in GH-promotion of cell survival. Activation of AKT depends on JAK2 binding to box1 in the GHR (135). Another kinase, p70S6K, involved in the control of cell proliferation and differentiation was shown to be activated by GH through PI-3 kinase and protein kinase C (PKC) (136). The NFkB pathway has also been shown to be activated by PI3-K and downstream AKT after GH stimulation (137).

\section{GH Desensitization}

Termination of the GHR signaling is an important mechanism for controlling GH actions (Figure 4). Protein tyrosine phosphatases (PTPs) are employed by the cells for negative regulation of $\mathrm{GH}$ signaling, namely $\mathrm{SH} 2$ domain-containing protein-tyrosine phosphatase (SHP-1), SHP-2, protein-tyrosine phosphatase (PTP)-H1, PTP1, TC-PTP, and PT1b (138). Mice, deficient in SHP-1, have prolonged JAK-2 phosphorylation and STAT5b activity, which represents strong evidence for an important role of this phosphatase in the deactivation of GH signaling (139). There are conflicting reports concerning the physiologic importance of SHP-2 in GHR: while Frank et al. concluded that SHP-2 is a positive regulator (140), Stofega et al. proposed SHP-2 as an inhibitor of $\mathrm{GH}$ signaling (141). GH stimulation has been shown to trigger the phosphorylation of JAK2-associated SIRP- $\alpha$, signal regulatory protein alpha. This was suggested to promote SHP-2 recruitment and consequent attenuation of GH signaling (142). A study by Pasquali has identified PTP-H1, PTP1, PTP1b, and TC-PTP as specific interactors of phosphorylated GHR (143). PTP1b knockout mice display increased JAK2 and STAT5b phosphorylation, while PTP-H1 knockout mice display enhanced growth $(144,145)$. CD45 was shown to be a JAK2 phosphatase, being able to suppress its activity and regulate cytokine receptor signaling (146).

Other regulators are PIAS, "protein inhibitors of the activated STATs", which display SUMO ligase activity. PIAS can bind STAT proteins, and prevent their association to the DNA. Although the majority of the PIAS interactor proteins are prone to modification by SUMO, the exact mechanism by which PIAS influences STAT5b function is still unclear (147). Some studies have also implicated the adaptor protein Grb10 as regulator of GH signaling. Grb10 interacts with GHR upon GH stimulation, and downregulates $\mathrm{GH}$ signaling pathways downstream of JAK2 and independently of STAT5b (148). Work of Carter-Su and colleagues found that $\mathrm{SH} 2 \mathrm{~B}-\beta$ association with JAK2 enhances its activity (149). Thus, decrease in SH2B- $\beta$ levels could contribute for $\mathrm{GH}$-signaling termination. Other cellular factors that modulate GH sensitivity are insulin, thyroid and sex hormones, as well as inflammatory cytokines $(150,151)$.

In addition to direct interference with the signaling molecules, cells have the capacity to tune the number of GHRs at the cell surface in several ways. As described above, the extracellular domain of GHR can be cleaved in a process called shedding. One of the consequences of this process is the reduction of the number of signaling competent receptors at the cell surface, and consequent regulation of the cell sensitivity to GH (124). Since GH binding to GHR inhibits its shedding, this mechanism cannot be regarded as signal terminator $(152,153)$. However, the most powerful and best studied mechanism to control GH sensitivity of cells is endocytosis. Opposite to other type 1 cytokine receptors, GHR is endocytosed both in the presence and absence of ligand $(154,155)$. Therefore, besides regulating the responsiveness of the cells to $\mathrm{GH}$, endocytosis of GHR provides a very efficient way for GH signaling attenuation. The next paragraph will be dedicated to the advances made in understanding GHR endocytosis.

\section{THE UBIQUITIN SYSTEM IN RECEPTOR TRAFFICKING}

Ubiquitin is a small molecule of 76 amino acids which Cterminus is attached to proteins upon sequential action of three enzymes: a ubiquitin activating enzyme (E1), a ubiquitin conjugating enzyme (E2), and a ubiquitin protein ligase (E3). Ubiquitin may be added as a single monomer or multiple monomers, or as a polyubiquitin chain. The addition of ubiquitin to target proteins covers a great variety of functions. Endocytosis is the main way used by the cells to achieve the 
homeostatic regulation of plasma membrane protein abundance. Once a protein is endocytosed it is either recycled back to the cell surface or captured in the intraluminal vesicles of the MVBs, and eventually guided to lysosomes for degradation (156).

Ubiquitination has emerged as a central mechanism governing the subcellular trafficking of proteins, reviewed in (7). It is critically important for the regulation of the number of receptors and transporters at the plasma membrane. The first evidence for a role of ubiquitin in the membrane trafficking came from the work of Kölling and collaborators with the ABCtransporter Step6 in yeast (157). In mammalian cells, the first receptor reported to depend on the ubiquitination system for its endocytosis and degradation was GHR (3). From then on, many more receptors were shown to depend on the ubiquitin system to be endocytosed, often in response to ligand binding $(7,158)$.

Ubiquitination works as an engagement tool of the proteins with the endosomal sorting complexes required for transport (ESCRTs) (159). In fact, ubiquitination has been reported at several points along the endocytic pathway. Although monoubiquitination has been regarded as a sufficient signal for sorting, K63 linked polyubiquitin chain are now considered as the primary sorting factor. Studies with the GAP-1 permease indicated that monoubiquitination is sufficient for initial internalization, but further sorting in the endosomes requires K63-linked polyubiquitin (160). Also studies of the mammalian TrkA and MHC class 1 proteins showed the importance of this type of chains in their MVB sorting $(161,162)$. Within the endocytic system, ubiquitin acts as an interaction module that is recognized by a variety of ubiquitin binding domains (UBDs), including UIM, CUE, NZF, and certain VHS and SH3 domains present in several proteins (163). As illustrated in Figure 2, after endocytosis, the next step in the sorting route is the selection by the ESCRT-0 complex, which acts at a branch point in endosomal traffic: binding to certain cargo (like the GHR) commits it to degradation in the lysosome, while cargo that does not bind (like transferrin and Low Density Lipoprotein receptors will be recycled to the plasma membrane. ESCRT-0 is composed of HRS and STAM, both of which bearing UIM (ubiquitin interacting motif) and VHS (Vps27, HRS and STAM) domains, important for ubiquitin binding and cargo recognition (164-166).

Other important components to consider in the endocytic regulation are the deubiquitinating enzymes (DUBs), which are specific proteinases able to remove ubiquitin moieties from proteins. Besides the catalytic domain, DUBs contain domains that allow them to associate with scaffolding proteins and adaptors. The ESCRT machinery associates with at least two DUBs: AMSH and USP8 (UBPY). In yeast, Doa4 has been identified as an additional DUB, important for receptor recycling. Deubiquitination of endocytosed receptors before or after delivery into the MVBs may profoundly affect receptor trafficking, and ultimately substrate turnover rate (167). It remains unclear how the ubiquitinated cargo is handed from one sorting step to the other. Models have been put forward based on a gradient of sorting proteins containing ubiquitin binding domains of increasing binding affinities. More complexity can be added to this model if we consider ubiquitin ligases such as Triad1 and DUBs along the sorting pathway, which could perform additional chain editing $(156,168)$. In Figure 5, the different controlling factors are depicted with reference to their effects on residence time at the cell surface and consequences of loss of function for the GH/IGF-1 axis.

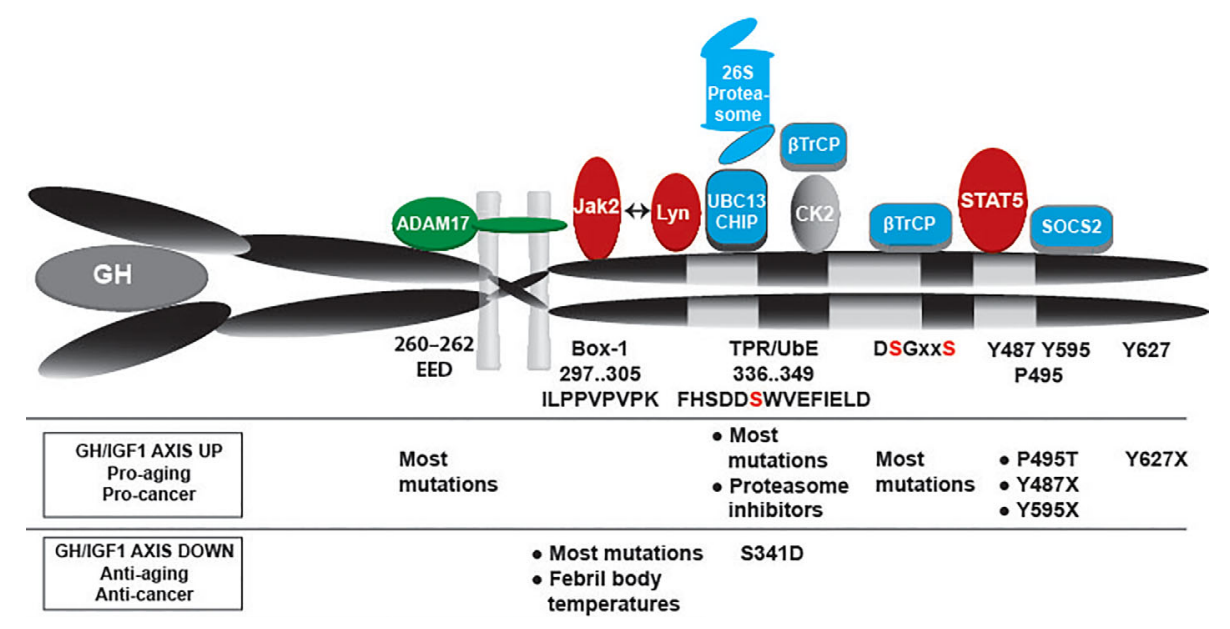

FIGURE 5 | GHR controlling factors: ADAM17, JAK2, Lyn, Ubc13/CHIP, proteasome, $\beta T r C P$, STAT5b, SOCS2 and possibly CK2. Their respective bindings sites are indicated. JAK2 and Lyn bind to the same membrane-proximal region, with overlapping substrate binding sites. Under basal conditions $\beta$ TrCP binds to the constitutively phosphorylated DSGxxS sequence. The kinases responsible for DSGxxS phosphorylation are unknown. Under conditions of GH stimulation JAK2 is released from the receptor, and the serine 341 of the UbE motif gets phosphorylated probable by CK2. These events increase the affinity of $\beta T r C P$ for the UbE motif, reduce the role of the DSGRTS sequence, and recruit STAT5b and SOCS2 to their respective binding sites (pY containing motifs). Overall, GH stimulation shortens the residence time at the plasma membrane and results in faster GHR endocytosis. The lower part indicates the effects of mutations and other conditions that might impact the GH sensitivity of cells: increased GH/IGF-1 activity acts pro-aging and pro-cancer, while lower activity acts anti-aging and anti-cancer. 


\section{Role of SCF ${ }^{\mathrm{TrCP}} \mathbf{1}$ in GHR Endocytosis}

The SCF (SKP1-CUL1-F box protein) subfamily of E3 ligases was originally discovered and studied in budding yeast Saccharomyces cerevisae (Patton et al., 1998). They are the best characterized mammalian cullin RING ubiquitin ligases. The determination of the crystal structure of SCF complex by Zheng and co-workers added some insights in the roles of each of its components and the mechanistic aspects of their interlinked actions (Zheng et al., 2002; Frescas and Pagano, 2008).

The endocytosis and degradation of GHR depends on the ubiquitin conjugation system, as shown for the first time in a Chinese hamster lung cell line (ts20) with a temperaturesensitive mutation in the E1 enzyme. Whereas at the permissive temperature the endocytosis of GHR occurred normally, when the cells were put at non-permissive temperature the GHRs accumulate at the cell surface (3). Further evaluation revealed that GHR ubiquitination and clathrin dependent-GHR endocytosis are coupled events $(40,41)$. An important achievement in the mechanistic understanding of GHR endocytosis was the discovery of the "Ubiquitin-dependent endocytosis motif", UbE, 340-349, which consists in the amino acid sequence DSWVEFIELD (169). If this motif is mutated the ubiquitination and endocytosis of GHR are strongly inhibited. Besides this motif, there is a di-leucine motif at the position 365366. This motif mediates fast ubiquitin-independent, clathrindependent GHR endocytosis only if the receptor is truncated at position 367, probably due to its complete exposure in this case. The functionality of the di-leucine motif in the context of fulllength receptor is not apparent (170). Surprisingly, a GHR truncation (at amino acid 417), where all its lysines were mutated to arginines, although not being ubiquitinated, was normally endocytosed in a ubiquitin-system dependent manner. This indicates that the ubiquitination of GHR itself is neither needed for its endocytosis nor for its degradation (169). One reason that justifies the importance of the UbE motif in GHR endocytosis is its binding site for the $\mathrm{SCF}^{\beta \mathrm{TrCP}} \mathrm{E} 3$ ligase (171). The role of the UbE motif and $\beta \mathrm{TrCP}$ has been also extended to sorting at the MVB and degradation at the lysosomes (172). JAK2 was also identified as a stoichiometric regulator of GHR endocytosis. Besides its role in signaling, merely binding of JAK2 to GHR is inhibitory for its endocytosis. As many cytokine receptors are JAK2 clients, cellular levels of JAK2 play a role in cytokine sensitivity, best illustrated by its sensitivity to febrile temperatures (103). The model is that GHR can only be endocytosed if JAK2 has detached from it, which was proposed to occur after GH stimulation. It is possible that JAK2 binding/ dissociation cycles have direct effects in the ubiquitination events mediated by $\mathrm{SCF}^{\beta \operatorname{TrCP}}$, and thereby affect rate of GHR endocytosis (92). Not surprisingly, the life cycle of JAK2 is controlled by E3 ubiquitin ligases of the CBL family as has been shown in hematopoietic stem cells and myeloid malignancies (173).

The UbE motif works as a recruitment platform for $\beta \mathrm{TrCP}$, the F-box substrate recognition subunit of $\mathrm{SCF}^{\beta \mathrm{TrCP}} \mathrm{E} 3$ ligase, necessary for GHR endocytosis (171). Generally, SCF ${ }^{\beta \operatorname{TrCP}}$ recognizes the classical DSGxxS motif in its substrates (174), including receptors homologous to GHR, such as prolactin receptor (PRLR) (175), interferon- $\alpha$ receptor (IFNAR) (176), and erythropoietin receptor (EpoR) (177). In these receptors, $\beta \mathrm{TrCP}$ binds only upon ligand binding when the serine residues in the DSGxxS motif are phosphorylated, which leads to their endocytosis and signal termination. The GHR also contains a $\mathrm{D}^{383}$ SGxxS motif. This is constitutively phosphorylated, able to bind $\beta \mathrm{TrCP}$, and contributes to the steady state endocytosis of the GHR (the half-life of unligated (mature) GHR is $30 \mathrm{~min}$ ) (39, 42). Therefore, in contrast with other cytokine receptor family members, GHR DSGxxS motif does not seem to contribute to signal termination. This role is carried out by the UbE motif, important for both steady state and GH-induced endocytosis (42, 92). NMR experiments demonstrated that the UbE motif is essentially unstructured, and, together with functional mapping of the UbE and $\beta \mathrm{TrCP}$ revealed a unique interaction model of $\beta \operatorname{TrCP}$ with GHR-UbE (178). Since the regulation of $\beta \operatorname{TrCP}$ substrates interactions involves serine phosphorylation, we evaluated the potential role of the UbE serine phosphorylation (S341) as a modulator of UbE- $\beta \operatorname{TrCP}$ interaction. Binding studies comparing affinities of the interaction of $\beta$ TRCP to unphosphorylated vs phosphorylated S341 peptides (Surface plasmon resonance and pulldowns) showed 100 times increase in binding affinity upon S341 phosphorylation. Accordingly, ${ }^{125} \mathrm{I}-\mathrm{GH}$ binding/internalisation assays in cell lines stably expressing S341A or S341D (phosphomimetic) suggest that $\mathrm{GH}$ stimulation triggers faster GHR endocytosis by causing phosphorylation of S341 in the GHR UbE motif and subsequent increase in UbE- $\beta$ TrcP binding affinity (179). S341 phosphorylation might constitute a very efficient mechanism for signal termination after GH stimulation.

The kinase responsible for S341 phosphorylation is unknown yet. S341 is contained in a minimal consensus site for CK2 phosphorylation, which has been identified to be S-X-X-Acidic. The acidic residue may be glutamate, aspartate, or phosphorylated serine and tyrosine: in case of S341 this sequence is $S^{341} \mathrm{WVE}$ $(180,181)$. Preliminary studies on the evaluation of a potential role for CK2 in S341 phosphorylation, by using the CK2 inhibitor 4,5,6,7-tetra-bromo-benxotriazole (TBB) (182), revealed that CK2 is a promising target. It has become apparent that the regulation of CK2 involves regulated expression, assembly and subcellular localization, post-translational modifications, and regulatory interactions with molecules and proteins (183, 184). Interestingly, there are reports of increased CK2 activation by insulin, EGF, IGF-1 $(185,186)$ and TNF $(187,188)$. EGF-activated ERK2 binds directly CK2 $\alpha$ enhancing its activity (189). TNF $\alpha$ induced activation of CK2 was also related to ERK1/2 activity (187). It is interesting to evaluate whether CK2 can be activated by $\mathrm{GH}$. Other stressors or pathways that activate ERK1/2 may result in increased activity of CK2 towards S341 in GHR, resulting in increased GHR endocytosis. Future studies will elucidate this hypothesis.

\section{The SOCS Family and GHR}

The suppressor of cytokine signaling (SOCS) family of proteins plays a very important role in the GH-signal termination. This family is composed of eight members, and the expression of four 
of them is stimulated by GH, namely SOCS1, $-2,-3$, and CIS (cytokine inducible SH2-constaining protein) (138, 190). Structurally, SOCS proteins contain a central SH2 domain and a motif called SOCS box at their C-termini (138). The SOCS box mediates the formation of multi-subunit ubiquitin ligases, containing elongin $\mathrm{BC}$, cullin 2 or 5 and the RING finger proteins Rbx1 or Rbx2 (191). SOCS1 and SOCS3 contain an additional kinase inhibitory region at their N-termini (KIR). Different SOCS apply different mechanisms for GH signaling downregulation. SOCS1 is thought to bind Y1007 on JAK2 activation loop, and by doing so, to inhibit JAK2 activity through KIR (192). SOCS3, besides binding to the same residue in JAK2 (193), also binds to phosphorylated tyrosines in GHR. Also, SOCS2 and CIS have been shown to bind to phosphorylated GHR, which was suggested to interfere with STAT5b-GHR binding (194). SOCS1, and possibly SOCS2 and SOCS3 use their ubiquitination activity to mediate GHR and JAK2 degradation and, therefore, signal termination (21, 104, 138). A role of CIS as a stimulator of GHR internalization and proteasomal degradation has been proposed (195). Interestingly, there is evidence that some stimuli that reduce GH sensitivity, such as estrogen or sepsis, do so by increasing expression of certain SOCS proteins $(196,197)$. The physiological importance of SOCS in GH signaling regulation is unclear since SOCS1 ${ }^{-/}$, $\mathrm{CIS}^{-/-}$and liver specific SOCS3 ${ }^{-/-}$are not bigger than normal (198-200). Only SOCS2 knockout mice are larger than wild-type (201). SOCS2 inhibits the GHR via binding to pY487 and pY595 $(202,203)$. SOCS may play a key role in shifting GH action from growth-promotion to lipolysis. Two independent studies showed that a single-nucleotide polymorphism in GHR resulting in a P495T substitution was associated with lung cancer $(204,205)$. Y595 (and Y487) were previously indicated as a binding site for the phosphatase SHP2 (141) Recently, Chhabra and collaborators showed a causative relation with SOCS2 binding to the GHR in which both P495 and pY487 are required (21). They show that GH-induced signaling increased AKT pT308 signaling significantly in GHRP495T cells. This is a strong prognostic indicator for non-small cell lung cancer (206). In addition, STAT3 was activated. Activated STAT3 is an important oncogenic factor during carcinogenesis and metastasis of both small cell lung cancer and squamous cell lung carcinoma (207). Taken together, SOCS family members, especially SOCS2, play an important role in the regulation of the GHR.

\section{CHIP and GHR}

In an effort to identify additional ubiquitination factors involved in the fate of $\mathrm{GH}$ receptors we used a small siRNA library targeting a selection of ubiquitination factors (35). As K63-linked ubiquitin chains have been implied in the regulation of membrane receptor trafficking, we search for such factors (160, 208). Silencing of the ubiquitin conjugase (E2) UBC13 came up as a GHR-specific endocytosis factor $(165,209)$. Previously, pulldown experiments showed that the UbE motif has an affinity for tetratricopeptide repeat-containing (TPR) proteins (30). As UBC13 can serve as E2 for a ubiquitin ligase that binds substrates via its TPR motif we tested both (C-terminus of
Hsp70 interacting protein) $\mathrm{CHIP}$ and $\mathrm{UBC} 13$ for endocytosis and degradation of the GHR: both factors were required and collaborated in GH-induced endocytosis of the GHR (209). Using blue native electrophoresis, Sedek et al. confirmed K63linked proteins in large GHR-containing protein complexes stimulated and isolated through streptavidin pull-down during endocytosis (27).

CHIP is an E3 ubiquitin ligase that plays a pivotal role in the protein quality control system by shifting the balance of the folding-refolding machinery toward the degradative pathway in order to maintain balanced proteostasis networks (33, 210-212). CHIP is highly expressed in tissues with high metabolic activity and protein turnover. In addition, as a regulator of growth and metabolism, CHIP mediates monoubiquitination and subsequent endocytic-lysosomal turnover of the insulin receptor (INSR). CHIP deficiency results in increased INSR levels that lead to premature aging in various organisms. The detrimental effects of the increased INSR level are mainly due to a PI3K/AKT signaling (213). In line with this, CHIP ubiquitinates AKT independent of its phosphorylation state (214). Remarkably, transcription of CHIP is also modulated in response to changes in AKT levels (215). Similar to AKT regulation, CHIP indirectly impacts the FOXO function on various levels through modulation of upstream substrates of the insulin/IGF-1 signaling pathway, a pivotal genetic program regulating cell growth, tissue development, metabolic physiology, and longevity of multicellular organisms (210). Thus, CHIP integrates proteostasis and aging by regulation the turnover of the INSR (211). In cancer the pathogenic mechanisms of CHIP are less clear (216). Several studies on breast cancer cells have indicated CHIP as tumor suppressor (212, 217-219).

\section{PHYSIOLOGICAL ROLES OF GH}

\section{Promotion of Growth}

The promotion of postnatal growth is a major physiological function of GH. Initially, it was thought that GH indirectly stimulates growth via triggering the production of IGFs, or somatomedins, exclusively in the liver. This was called the "somatomedin hypothesis". This theory was challenged when direct actions of $\mathrm{GH}$ on several peripheral tissues were reported (220). In fact, liver-specific IGF-1 gene-deleted mice show normal postnatal growth and development despite the low levels of IGF-1 in circulation. This indicates that direct effects of GH in target tissues (adipose tissue, bone and skeletal muscle) are involved in growth promotion, and probably in stimulation of local IGF-1 production (221). According to the dual effector hypothesis of Green et al. GH may stimulate early recruitment of stem cells followed by further clonal expansion due to $\mathrm{GH}$ induced IGF1 expression (222). The critical importance of GH as the main endocrine mediator of growth is proven either by the dwarf phenotype occurring when the levels of GH are insufficient during early development, or by gigantism, due to hypersecretion of GH before puberty (53). Apart from GH secretion, also defects in GHR and post-receptor signaling may result in 
phenotypes similar to GH hypo-secretion. Laron and coworkers described for the first time the clinical phenotype of severe growth defect, and for that reason it is named "Laron Syndrome" (223). Deletions and mutations in GHR have been described as causative for this phenotype $(224,225)$. Studies on a large cohort of individuals in northeastern Brazil who were homozygous for a mutation in the GH-releasing hormone receptor gene revealed comparable phenotypes. These individuals are characterized by severe dwarfism, due to very low GH and IGF-1 levels, increased adiposity, and increased insulin sensitivity (226). Lean body mass (LBM) is reduced, but muscle function is adequate. Their longevity and quality of life are normal, and they are largely protected from cancer and less prone to atherosclerosis (227).

Postnatal growth of mice has been shown to rely on signaling mediated by JAK2 and STAT5. GHR-/- mice with knock-in GHR1-391, which eliminates all GH-mediated STAT5b signaling while still allowing activated hepatic JAK2 and ERK2, showed substantially decreased growth (228). This study identified many genes as STAT5b-regulated, such as IGF-1, Igfals, Socs2, P450 cytochrome, Cyp2b9, and some metabolic enzymes. Eleven of these were upregulated (e.g., Sth2, Hao3, and Ang), and nine were downregulated (e.g., Igfals, IGF-1, EgfR, and Comt). These results confirm the importance of STAT5b in growth promotion. On the other hand, pituitary adenomas that cause hypersecretion of GH result into excessive growth called gigantism when present before puberty, whereas in adulthood it results in a clinical condition called acromegaly (229). In these patients excess of $\mathrm{GH}$, besides affecting the size of hands, feet, and fingers, has important metabolic consequences, suggesting additional functions for $\mathrm{GH}$, that will be discussed next in this review.

\section{Metabolic Regulation}

$\mathrm{GH}$ holds important roles in metabolic regulation (Figure 6). As soon as human pituitary extracts became available it was shown that injection of large amounts of GH both in healthy subjects and GH-deficient patients stimulated lipolysis and led to hyperglycemia (230-232). Indeed, as expected, hyperinsulinemia, impaired glucose tolerance, and overt diabetes mellitus are common features of acromegaly (233). GH works as a metabolic switch between carbohydrate and lipid utilization: in conditions of energy surplus GH acts in concert with IGF-1 to promote nitrogen retention, while during starvation $\mathrm{GH}$ switches fuel consumption from carbohydrates and protein to lipids. This guarantees the preservation of protein stores and consequently maintains LBM. The direct acute metabolic effects of GH in the basal state are the stimulation of lipolysis and the consequent increase of free fatty acids (FFA) in the blood. Repetitive GH pulses in presence of adequate energy supply and concomitant increased insulin levels induces IGF-1 production $(234,235)$. Consequently, in the long range, protein stores and LBM increases, while body fat mass decreases. GH stimulates the cell growth of the skeletal muscle by facilitating myoblasts fusion. Like in more peripheral tissues GH does not regulate IGF-1 expression in myotubes. On the other hand IGF-1 has been implicated in skeletal muscle hypertrophy, attenuation of agerelated skeletal muscle atrophy, and restoring and improvement of muscle mass $(236,237)$.

Studies evaluating the acute effects of $\mathrm{GH}$ on protein metabolism in the basal state have produced inconsistent conclusions. While some studies indicated that acute $\mathrm{GH}$ stimulation leads to increased muscle protein synthesis, others did not detect any effects of GH withdrawal in protein metabolism (238). Less controversial are the studies evaluating the effects of

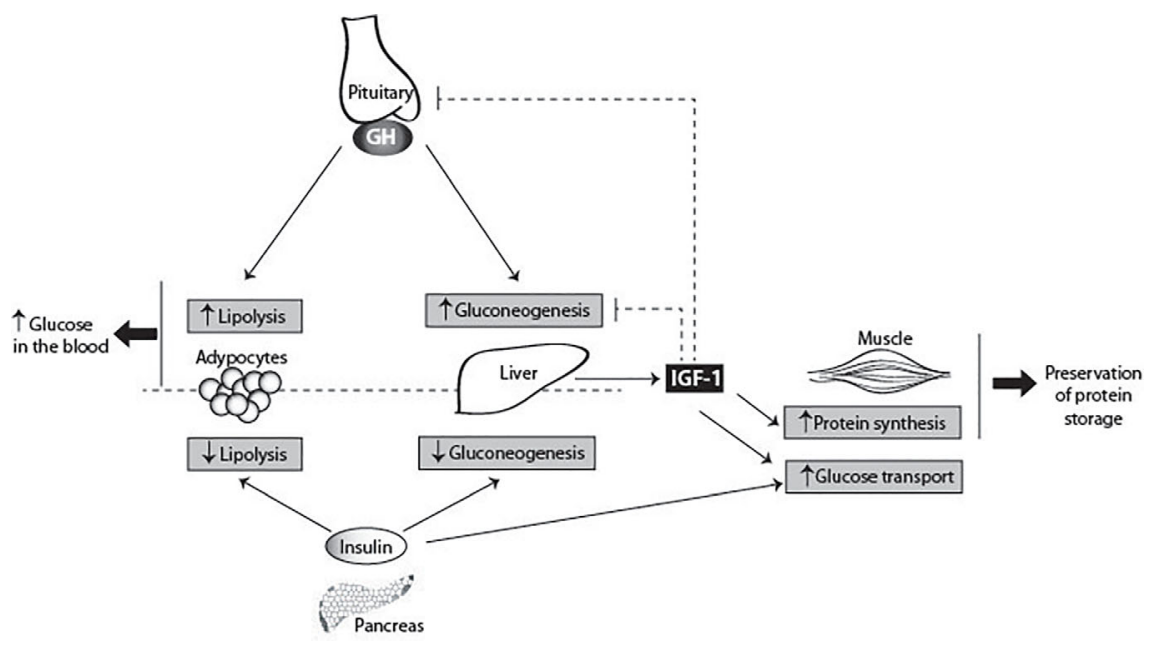

FIGURE 6 | GH metabolic actions. GH has pleiotropic effects on carbohydrate, lipid, and protein metabolism. GH antagonizes the effects of insulin, secreted by the pancreas, by two direct ways: inhibiting gluconeogenesis in the liver, and increasing lipolysis in adipocytes. GH also stimulates the production of IGF-1 by the liver. IGF-1 suppresses gluconeogenesis in the liver via the insulin receptor. In the muscle, IGF-1 stimulates directly glucose uptake, and stimulates protein synthesis. IGF1 inhibits GH secretion by the pituitary gland, and therefore indirectly blocks the insulin antagonizing effects of GH, contributing for the glucose homeostasis. The main consequences of $\mathrm{GH}$ metabolic actions are the increase of glucose levels in the blood and preservation of protein storages. 
$\mathrm{GH}$ on protein metabolism in pathological states (acromegaly and $\mathrm{GH}$ deficiency) and in stress (exercise and fasting). Stress conditions are the natural domains of $\mathrm{GH}$, in which the body benefits from GH effects on substrate metabolism (238). During fasting GH is the only anabolic hormone to increase (239). GH administration has been shown to be beneficial for protein preservation in conditions of dietary restriction (240). Moreover, fasting in $\mathrm{GH}$-deficient subjects resulted in $50 \%$ increase in ureanitrogen excretion and $25 \%$ increase in muscle protein breakdown $(241,242)$. Also, obesity has been associated with decreased levels of circulating GH, and consequent protein loss (243). Treatment of these patients with $\mathrm{GH}$ has been successful in preserving the protein stores and LBM (244). Although the metabolic functions of $\mathrm{GH}$ are well recognized, the underlying mechanisms of these actions are not yet well described.

Under certain conditions (e.g. if cells are deprived of $\mathrm{GH}$ for some hours), GH has acute and transient insulin-like effects (134). These effects include increased glucose utilization, increased glucose uptake, anti-lipolysis among others. It has been suggested that these effects are mediated by the insulin receptor substrate-1 (IRS-1) and phosphoinositide 3-kinase (PI3$\mathrm{K})$, which get activated by GH stimulation (245).

There is an extensive interest in taking advantage of the anabolic effects of GH for improving athletic performance (246). During moderate exercise $\mathrm{GH}$ appears to stimulate lipolysis without any effect on protein and glucose metabolism. Prolonged GH administration results in prevalent lipolysis and decreased protein oxidation (238). Although administration of supra-physiological doses of $\mathrm{GH}$ to athletes exerts potentially beneficial effects on body composition, it remains unclear whether these effects translate to improved performance (247). Nevertheless, GH abuse has been widespread among the athletes for more than 20 years, with consequences such as edema, carpal tunnel syndrome, arthralgias, myalgias, glucose intolerance and diabetes mellitus $(248,249)$.

\section{Roles in the Immune System}

At the cellular level, GH stimulates differentiation and mitogenesis and prevents apoptosis $(137,145,250)$. There are also reports that $\mathrm{GH}$ signaling results in tubulin polymerization (251), cell migration and chemotaxis (252). These cellular effects are implicated in a variety of biological actions of $\mathrm{GH}$ in immune cells. Both $\mathrm{GH}$ and its receptor are expressed in various immune cells as T lymphocytes, B lymphocytes, monocytes and neutrophils. GH enhances thymopoiesis and $\mathrm{T}$ cell development, modulates cytokine production, enhances B cell development and antibody production, activates neutrophils and monocytes, enhances neutrophil adhesion and monocyte migration, and it has an anti-apoptotic action (253). Additionally, $\mathrm{GH}$ is involved in the formation and functional activation of mature blood cells (254).

GHR clearly acts in favor of an active immune system. In aging people the immune response gradually deteriorates due to a downregulated GH/IGF-1 axis (238). This became particularly clear during the Covid-19 pandemic in 2020 when death rates were very high among elderly. Lowered GH/IGF-1 activity promote inflammatory activity, causing long term tissue damage and systemic chronic inflammation due to decreased levels of anti-inflammatory adipokines such as adiponectin (255). Somewhat counterintuitive, studies of long living mutants and caloric restricted animals show decreased pro-inflammatory activity with increased levels of antiinflammatory adipokines such as adiponectin. This suggests that reduced inflammation promoting healthy metabolism may represent one of the major mechanisms of extended longevity in long-lived mutant mice and likely also in the human. Together it shows that there is a need for insight in the molecular mechanisms underlying the relation between the GH/IGF-1 axis and immunity. Recently, Ishikawa et al. found that induction of the mouse major histocompatibility complex (MHC) antigen blastocyst $\mathrm{H} 2(\mathrm{H} 2-\mathrm{Bl})$ expression by $\mathrm{GH}$ is critical for suppressing innate immune cells such as natural killer (NK) cells/NK T cells (NKTs) and macrophage-mediated hepatocyte apoptosis, which favors C57BL/6 mice liver regeneration and survival after partial hepatectomy. Application of human leukocyte antigen G (HLA-G, the human homolog of $\mathrm{H} 2-\mathrm{Bl}$ ) gave similar results (107). They used a series of knock-in mice to prove that, rather than the JAK/STAT pathway, GHR signaling from SRC, presumably Lyn, bound to the GHR receptor, activates ERK via RAS $(85,106)$. Thus, $\mathrm{H} 2-\mathrm{Bl}$ expression is crucial for reducing innate immune-mediated apoptosis and promoting survival after partial hepatectomy. This is important progress on the long road to understand the relation between GH/IGF-1 signaling and immunity regulation.

\section{Roles in the Brain}

The activity of GH/GHR in the brain is still a matter of debate. $\mathrm{GH}$ has been described as modulator of stress response and behavior by acting directly on the brain (256). Recent studies show that $\mathrm{GH}$ has direct trophic effects on the formation of proopiomelanocortin- and agouti-related peptide-expressing neurons and provide evidence that $\mathrm{GH}$ regulates hypothalamic neurocircuits controlling energy homeostasis (257). IGF-1 is well known to be critical for neuronal structure and function, and models of IGF-1 deficiency demonstrate important hippocampal deficits, as reduced structural complexity, excitability, learning, and memory (258-261). Interestingly, low IGF-1 levels have been associated with risk for vascular dementias (262). On the contrary, studies with growth hormone deficient (GHD) people and mouse models support the notion that a decrease in $\mathrm{GH}$ action is beneficial for maintenance of CNS integrity and functions as learning and memory during aging (263-265). Both in humans and rodents, circulating GH and IGF-1 levels decline with age, including in the central nervous system (CNS) (266). However, despite low overall GH/IGF-1 levels, old Ames dwarf mice have elevated levels of GH and IGF-1 in the hippocampus. Also, human subjects with Laron syndrome show improved rather than impaired memory (13). A likely explanation for the disconnect between IGF-1 and GH roles in the brain was provided by Sun et al. who demonstrated that hippocampal IGF-1 expression is not reduced in GH-deficient mice (267). Importantly, studies by Efstratiadis provided 
evidence that in contrast to hepatic IGF-1 expression, IGF-1 expression in the brain is not GH-dependent (268). GHD and GHR deficient mice, which have longer life expectancies than wild-type, also perform better on cognitive tasks (255). Furthermore, three prominent models of GH signaling disruption-Snell dwarf, Ames dwarf, and GHRKO mice-all suggest reduced GH is beneficial to the CNS. Ames dwarf mice, which carry a homozygous loss-of-function mutation at the Prop-1 locus, are deficient in GH, thyroid-stimulating hormone (TSH), and prolactin-producing cells in the adenohypophysis. Despite their smaller body size and unique phenotype, these mice have a significantly increased lifespan and maintain physiological and cognitive function at youthful levels longer than controls $(269,270)$.

\section{GH and Aging}

Knockout mice for GHR ("Laron Dwarf") and mice with mutations causing GH deficiency or resistance ("Ames dwarf", and "Snell dwarf", and "Little") live longer than their genetically normal siblings (4, 227, 271-274). This extended longevity is remarkable and reproducible, ranging from $25 \%$ to over $60 \%$. These long-lived mice present many signs and indicators of a healthy delayed aging process. These results would lead to the conclusion that GH normally released by the pituitary limits life expectancy, probably due to acceleration of the aging process. This conclusion is supported by reports showing that reduced levels of IGF-1, or mutations interfering with IGF-1 signaling also result in increased mice longevity $(275,276)$. As expected, transgenic mice with elevated levels of GH and IGF-1 live shortly and reflect characteristics of an accelerated aging process (277). Studies analyzing the influence of GH signaling and lifespan in several species have been performed. Exciting new findings come from numerous tissue-specific GHRKO mice and include the role of $\mathrm{GH}$ in pancreatic $\beta$-cells to stimulate insulin following glucose challenge, in weight loss regulation in ablated AgRP neurons and in glucose homeostasis in LepR neurons. In muscle GHR disruption enhances insulin sensitivity and extends lifespan, while adult-onset global disruption of GHR extends female lifespan, reviewed in (278).

While Besson and co-workers reported that individuals with congenital GH deficiency live shorter (279), others reported that GH-deficient/resistant subjects live long with decreased incidence of cancer, atherosclerosis and vascular pathology, in spite of being obese $(11,280,281)$. These conflicting results may be connected to another key factor influencing the aging process: the insulin sensitivity. In mouse models, GH-deficiency is associated with insulin sensitivity (low levels of circulating insulin), while GH-deficient people are insulin resistant (high levels of circulating insulin). In these models, GH-deficiency allied with insulin sensitivity contributes to low blood glucose level. This biochemical feature has been negatively correlated with oxidative stress (282). Since oxidative stress is recognized as one of the major causes of aging (283), GH may influence the aging process by acting on oxidative stress pathways. Accordingly, Ames dwarf mice produce less metabolic oxidants, and have increased levels of anti-oxidants $(284,285)$. On the other hand, in GH-deficient humans, insulin resistance increases the oxidative damage (282), induces accumulation of visceral fat mass (286), and increases the risk of several agerelated diseases $(12,210,287)$. Thus, differences in the aging process between mice and humans suffering from GH-deficiency may be explained by their difference in insulin sensitivity.

Recent studies show physical and functional interactions of GHR with IGF-1R, which might strengthen its role in aging (and cancer). Although absent in hepatocytes, IGF-1R can serve as a component of the GH signaling pathway, modulating GHR's signaling strength and allowing for more local heterogeneity of GH/IGF-1 actions (86). Not only the GH-induced IGF-1 expression in the liver, also its secretion is subject of regulation. Studies of the energy sensing liver kinase B1-AMPactivated protein kinase (LKB1-AMPKa1) pathway implicate this pathway in the IGF-1 secretion via the small GTPase, Rab8a: the LKB1-AMPK pathway inhibits IGF-1 secretion. How this relates to the tumor suppressor functions of LKB1 remains unclear. Independent of the LKB1-AMP-activity, the insulin sensitizer and anti-aging/cancer agent, metformin also inhibits IGF-1 secretion (288-290). Once again, these studies illustrate the complexity of the GH/IGF-1 axis for metabolism, in homeostasis, as well in aging and cancer.

In humans, during aging the GH/IGF-1 axis is down regulated (238). On one hand, this probably contributes to the effects of aging on body composition, skin characteristics and functional changes that decrease the quality of life. On the other hand, decrease in the amounts of GH with age may offer protection from cancer and other age-related diseases. Therefore, GH replacement is controversial as an anti-aging therapy and involves both benefits and risks $(274,291)$.

\section{GH and Cancer}

There is an overwhelming number of studies that implicate GH/IGF-I in cancer growth. Organisms that lack GHR activity are virtually devoid of cancer $(4,292-299)$. In addition to the pituitary, GH is expressed in colon, prostate, lung, meningiomas and breast, where it binds the GHR to signal in a paracrine/ autocrine fashion (21, 297, 300-303). Elegant experiments with rodents reveal an important role of $\mathrm{GH}$ in tumor development. Crossing GHR KO mice with mice predisposed to develop carcinomas significantly slowed down tumor progression (304). Additionally, $\mathrm{GH}$ deficient rats crossed with rats predisposed to prostatic cancer showed significantly reduced tumor incidence and burden (305). Interestingly, GH-deficient female rats are resistant to chemical induction of mammary carcinogenesis, whereas GH replacement restores the risk of tumor development (306). Intracellular (autocrine) GH promotes breast cancer cell transformation $(292,294,301,307,308)$ and induces an invasive phenotype by triggering an epithelialmesenchymal transition (EMT), cell motility, and increased cell survival (295, 297, 300-302).

Strong epidemiological evidence shows that people without GHR (Laron dwarfism) live healthy normal lives despite low IGF1 levels. Strikingly, they do not develop cancer (nor diabetes), while overabundance of GH/IGF-1 links to cancer incidence (280, 292, 309). For common cancers (breast, colon, prostate, melanoma) tall size relates to cancer risk (308, 310-314). Most importantly, studies 
with cells, tissues and animals show that GH/IGF-1 stimulates growth of these same cancers, while cancer growth without $\mathrm{GH} /$ IGF-1 activity is absent $(57,294,300,301,305)$. Recent data suggest that also pancreatic ductal adenocarcinomas and small-cell and squamous-cell lung cancer are driven by GH/IGF-1 (21, 315, 316). Thus, there is solid evidence that both GH and IGF-1 are important cancer drivers in humans.

Most cancer cells express GH. This raises the possibility that autocrine GHR activation might be a cancer-driver. In breast cancer tissue, that is devoid of pituitary-specific POU domain transcription factor $1, \mathrm{GH}$ expression is stimulated by progesterone $(58,317)$. Approximately two-thirds of human breast cancers are steroid hormone receptor (ER/PR) positive and treated with combinations of selective estrogen receptor modulators. It is currently unknown whether their effect relies on inhibition of GH expression. Whether triple-negative breast cancer (TNBC) cells, that do not respond to these modulators, also depend on $\mathrm{GH}$ expression, is unknown. The GH-antagonist, pegvisomant, has been successfully used in cancer-derived cell lines (295), but does not inhibit autocrine-acting $\mathrm{GH}$ in cancer patients as it probably cannot interfere with intracellular GH/GHR signaling (82). Direct targeting of GH signaling is therefore most probably the only possibility for therapeutic intervention in most cancers.

$\mathrm{GH}$ treatment of intestinal organoids closely recapitulating normal human intestinal mucosa resulted in p53 suppression and increased Wnt (318). GH treatment leads to downregulation of E-cadherin, which controls cell adhesion and prevents tumor cell dissemination $(318,319)$. An interesting JAK-STAT3 and Wnt- $\beta$-catenin pathway connection was revealed that fuels the growth of intestine tumors. The study presents evidence that partial suppression of systemic JAK-STAT3 signaling is sufficient to limit tumor growth by reducing Bmi-1dependent repression of p21 and p16. Normally p21 is repressed by Bmi-1 in APC-mutant tumors $(320,321)$. This connection provides a route to use the GHR-STAT3 pathway for a therapeutic modality to inhibit APC mutant cancers.

A growing number of studies implicate $\mathrm{GH}$ also in development of therapeutic resistance in a variety of human cancers (322). Both JAK2- and Lyn-initiated pathways activate, upon anti-cancer treatment, many different systems that upregulate ABC-multidrug efflux pumps (ABCG2), block apoptosis, DNA repair (p53), and pro-apoptotic molecules (Bax, PPAR $\gamma$ ), suppresses caspase activation, and induce EMT and markers of stemness like ALDH1, NANOG, and CD24. In melanoma, GH upregulates the melanocyte-inducing transcription factor (MITF), that targets the oncogene MET, and organizes the resistance to radiation therapy (323).

\section{THE REGULATION OF THE GHR AT THE CELLULAR LEVEL}

Given the many factors that control the GHR activity it is important to integrate this knowledge into a concept. Except for autocrine signaling, the number of GHRs at the cell surface determines the sensitivity for GH. This is tightly controlled by the factors discussed above.

Within 20-30 min after synthesis in the ER, the GHR arrives at the cell surface, is available for $\mathrm{GH}$ binding during $30 \mathrm{~min}$, is endocytosed, and degraded within $5 \mathrm{~min}$. A good indication for this can be delineated from the ratio between the precursor form in the endoplasmic reticulum $(110,000 \mathrm{Mr})$ and the mature form at the cell surface $(130,000 \mathrm{Mr})$ if separated by SDS-PAGE and immunoblotted from a crude cell extract using an anti-GHR antibody: If this ratio is approximately $1: 1$ at steady state, it implies that each GHR is present at the cell surface for only $30 \mathrm{~min}$. Protease $\mathrm{K}$ treatment on ice shows that almost no $130,000-\mathrm{Mr}$ species is inside, on route to the lysosomes. In Figures 2, 5 the controlling factors are shown.

Based on data from literature combined with our own data we propose the following concept for GHR endocytosis. The major regulators are: ADAM17, JAK2, Ubc13/CHIP/Proteasome, CK2/ $\beta \operatorname{TrCP}, \beta \operatorname{TrCP}(\mathrm{DSGxxS})$, and SOCS2. In steady state (no GH), endocytosis is enabled by Ubc13/CHIP and $\beta \operatorname{TrCP}$ (DSGxxS). Both systems are necessary and sufficient. If JAK2 is activated, S341 is phosphorylated, presumably by an activated CK2, SOCS2 binds to pY487/pY595, and all 4 ubiquitination systems are necessary and sufficient for endocytosis. Inactivation of each impedes endocytosis and prolongs GHR signaling capacity. Summarizing the contribution of each enzyme system to $\mathrm{GH}$ sensitivity is as follows:

ADAM17 (TACE) contributes $\sim 10 \%$ to the inactivation of GHR (Figure 2). It is involved in the shedding of many membrane proteins and receptors. Its activation, whether that means increased presence at the cell surface, increased enzymatic activity via phosphorylation, or increased residence time at the cell surface is poorly documented. Many signaling pathways are known to promote ADAM17 phosphorylation including PKCs, ERKs, p38 MAPK and PLK2 (324). Shedding of the GH-GHR complex is prohibited $(39,48,152)$. Interestingly, Uev1A-Ubc13 (see below) mediates the classical TNF $\alpha$-induced $N F-\kappa B$ signaling pathway, and at the same time provides for a feedback loop together with CHIP to terminate NF- $\kappa \mathrm{B}$ signaling by facilitating ADAM17 maturation via RHBDF2 ubiquitination (325). It would not be surprising if GHR signaling would act on ADAM17 in an analogous way.

High JAK2 levels inhibit GHR endocytosis, but in normal cells and tissues this might be not relevant. In IM9 lymphoblasts high levels of JAK2 may prolong the life time at the cell surface (92), but in $\gamma 2 \mathrm{~A}$ cells, that do not express JAK2, GHR has a normal half-life (326). In addition to being controlled by ancillary factors such as SH2-B (91), their activities are subjected to auto-activation, they trans-phosphorylate tyrosine residues in specific patterns (327), they detach from activated receptors to be recycled by phosphatases (92), and in particular, JAK2 responds to heat stress by irreversible aggregation (103). Thus, elevated body temperatures lower the responsiveness of cytokine receptors, and consequently, contribute to a balanced immune system e.g. during a cytokine storm $(328,329)$.

Ubc13/CHIP/Proteasome are required for both unstimulated and GH-stimulated (pGHR) endocytosis (35). The exact 
mechanism is still unknown. The bottom-line is that endocytosis of the GHR is not possible if either proteasome activity, CHIP or Ubc13 are lacking. Other observations include: Endocytosis does not require lysine residues, and proteasome-independent endocytosis is only possible if the tail is partly truncated (40, 170). Given its nature as co-chaperone Ubc13/CHIP/Proteasome most likely act in a late step in GHR endocytosis, analogous to TPR proteins in quality control of mislocalized membrane proteins $(34,330)$. In an analogous way, we propose that CHIP binds with its first TPR motif to the UbE motif, with its central TPR motif to the proteasome and with its U-box to the ubiquitin conjugase Ubc13/UEV1a. Recruited by CHIP, the proteasome might remove the C-terminal part of the GHR downstream of the DSGxxS motif at amino acid 383: an action that explains why endocytosis of a truncated GHR requires both UbE and DSGxxS motifs, but no proteasomal activity (43). This is in line with our observation that degradation of the GHR cytosolic domain precedes degradation of the GH-binding domain (331). In this role CHIP cleans up and definitively terminates $\mathrm{GH}$ signaling at the cell surface. In such a scenario, proteasome inhibitors might be considered pro-cancer and pro-aging, as they prolong the residence time of the GHR at the cell surface $(39,209)$.

Phosphorylation of S341 in the UbE/TPR motif, presumably by $\mathrm{CK} 2$, is responsible for an $150 \%$ increase of the rate of GHR endocytosis and degradation (179). We showed that this is GHinduced, but also other conditions and stressors might stimulate S341 phosphorylation. Insulin has been suggested to reduce GHR levels and GH signaling in PI-3 kinase- and MAPKdependent manners (332-334). Also, IGF-1 and estrogen might use phosphorylation of S341 to decrease the pool of GHRs at the cell surface $(335,336)$. Pro-inflammatory cytokines such as TNF $\alpha$ and IL- 6 have been described to induce $\mathrm{GH}$ insensitivity. In the latter case, the kinase acts to desensitize cells for GH (337). Coincidentally or not, neighboring JAK2 that binds 45 amino acid residues upstream also is a CK2 client (338). If stressors phosphorylate the S341 in the UbE/TPR motif, the GHR endocytosis rate is increased, independent of SOCS2 (see below).

Phosphorylation of the DSGxxS motif: The DSGRTS sequence in GHR seems to be phosphorylated in basal conditions, without applying any special treatment or stressor to the cells (42). However, it is possible that under physiological conditions the phosphorylation status of DSGRTS might also be regulatable upon certain stimuli, as for the UbE/TPR motif. Additionally, in some situations that require high levels of $\mathrm{GH}$ signaling, the body would benefit from higher sensitivity to $\mathrm{GH}$ at steady state, e.g. in the process of chondrogenesis at children's growth plate, or during adolescence to stimulate breast growth, or at the end of mitosis if cells need to growth $(339,340)$. A decreased kinase activity towards the DSGRTS serine residues would result in decreased basal degradation of GHR, increase in cellular levels of GHR, and consequently increase in $\mathrm{GH}$ sensitivity.

SOCSs induce proteasomal degradation of targets through ubiquitination $(341,342)$. However, in case of transmembrane receptors like GHR and prolactin receptors it is less clear, whether they contribute only to their signal termination or also to their endocytosis/lysosomal targeting/degradation. SOCS2 binds to a degron sequence $\mathrm{TP}^{495} \mathrm{AGS}$ downstream of the STAT5b-interacting pY487. If P495 is mutated to threonine, the binding to SOCS2 is prevented, and the degradation of activated GHR (pGHR) is delayed (21). Assuming that the GHR-JAK2 complex initiates signaling only from the cell surface, the results of Chhabra and co-workers imply that pGHR can endocytose and be send to lysosomes, only after SOCS2 has acted on the pGHR (at the cell surface). In that case, SOCS2 is part of a concerted action together with JAK2, $\beta \operatorname{TrCP}$, and CHIP in initiating signal transduction and preparing the GHR for endocytosis (Figures 2 and 5). Increased time span between signal initiation and endocytosis intensifies $\mathrm{GH}$-induced signaling per GHR complex. In a previous study we showed that signal transduction can continue after endocytosis (343). At that time a clear distinction between events starting at the cell surface and continuing inside was difficult to make. Endocytosis of GHR with all tyrosine residues deleted is near normal (92). Thus, SOCS2 contributes only to the deactivation and endocytosis of pY487, pY595-GHR. If the GH/GHR signaling comes from inside (autocrine activation), as is assumed in many cancer cells, there are many open questions: Do the activated GH/ GHR complexes reach the cell surface or are they directly transported to MVBs, what are the signaling modes and capacities of these complexes and (how) is it regulated? These are important open questions to understand the role of the GHR in cancer growth.

STAT5b binding to tyrosine residues 487, 534, and 627 are most important for its activation (22). Like GHR knock-out mice, mice that express GHR(1-391) show insulin sensitivity with obesity (344). GH-mediated STAT5b activation acts on multiple sites in the major insulin responsive tissues to promote insulin sensitivity. These actions are regulated at both transcriptional and posttranscriptional levels, and although ChIP analysis indicates direct STAT5b action at the promoter level of key genes, it is apparent that many of the insulinsensitizing actions of GH-STAT5b deficiency are indirect.

Tyr627: In an effort to determine the contribution of individual tyrosine residues to the STAT5b and MAPK signaling pathways, we found that the Y627F mutation resulted in constitutive GHR, JAK2 and MAPK phosphorylation and activation (22). It is expected that this mutation would act as procancer and pro-aging, but to our knowledge, this variant has not been reported in humans yet $(345,346)$.

In this summary, the role of Lyn per se has not been discussed, as the molecular details as how it functionally interacts with JAK2 and the endocytosis machinery are unknown.

\section{CONCLUSIONS AND PERSPECTIVES}

In this review, we discussed enzyme systems that regulate the GH-sensitivity of cells by direct interaction (ADAM17, JAK2, $\beta \mathrm{TrCP}, \mathrm{CHIP}, \mathrm{SOCS} 2)$. As discussed in the previous section, except for JAK2, delayed activity of each of the systems predicts 


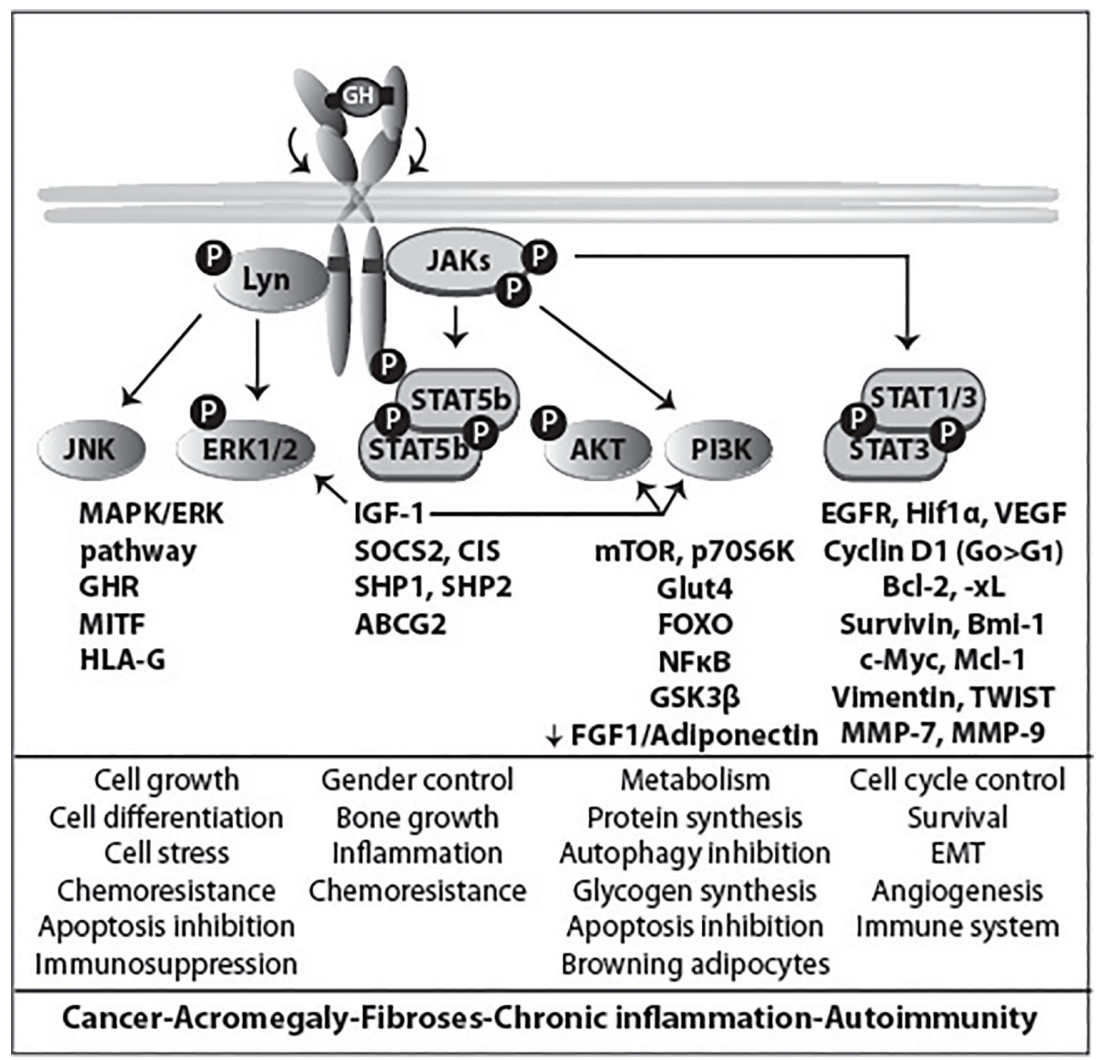

FIGURE 7 | GHR signaling and its span of control. GHR acts via JAK/STAT and Lyn, and controls many aspects of cell growth and differentiation, gender, metabolism and cell cycle (middle panel). The general scheme is in Figure 4. Deregulated downstream effectors have been studied in great detail in promoting many cancers and chronic diseases (lower panel).

prolongation of the GHR at the cell surface. As GHR synthesis continues, delayed endocytosis results in increased GHsensitivity. This is illustrated for SOCS2: prolonged $\mathrm{GH}$ signaling, due to a defective GHR-SOCS2 interaction, promotes cancer progression in human lung cancer $(21,202)$. Although the GH/IGF-1 axis is clearly involved in cancer, none of the other binding sites have yet been identified in genomewide association study $(204,205)$. Apparently, these sites are highly relevant for life and do not allow mutations.

Considering the GH/IGF-1 axis as the mains switch, downstream effectors are the executers of the many tasks (Figure 7) (116). Without exception, these factors function in various signaling pathways and are regulated not only by signaling receptors but also in networks of other stressors. Obviously, mutations in these crucial "house-hold factors" contribute to several chronic diseases. However, in many instances, they need the supervision of the GH/IGF-1 axis. As each of the enzyme systems impact the activity of the GHR similarly (less interaction results in higher GH-sensitivity) it is plausible that their presence in the regulation of the hierarchical command-and-control mode of the GHR indicates their importance for major control systems. Accordingly, their loss of function would result in the same effect as GHR gain of function. Upregulation of the GH/IGF-1 axis in adult species leads to chronic diseases as illustrated in Figure 7 (4-10, 12, 13, 347). Indeed, there are many studies that validate this hypothesis. Taken together, literature on CHIP and SOCS shows striking analogy with the regulatory potential of the GHR: organisms with increased CHIP and SOCS2 activity live longer and suffer less from chronic diseases. This is also observed for some of the downstream GHR effectors like mTOR (348). Controlling GHR turnover in the axis: GHRH $\rightarrow$ GHRHR $\rightarrow$ GH $\rightarrow$ GHR $(+\mathrm{IGF}-$ $1) \rightarrow$ Growth/Aging, is a challenging mission. Accomplishment will be highly rewarding as it might offer novel tools to fight the conditions, that underlie the major diseases of aging populations.

\section{AUTHOR CONTRIBUTIONS}

All the authors contributed equally. All authors contributed to the article and approved the submitted version. 


\section{FUNDING}

This work was supported by the European Network of Excellence, RUBICON "Role of ubiquitin and ubiquitin-like modifiers in cellular regulation", grant LSHG-CT-2005-018683; two European Union Marie Curie Networks, grant MRTNCT2006-034555 (UbiRegulators) and ERBFMRXCT96-0026; by the Dutch Technology Foundation Stichting Technische Wetenschappen (STW), which is the applied science division of the Nederlandse Organisatie voor Wetenschappelijk Onderzoek (NWO), and the Technology Program of the Ministry of Economic Affairs, Grant 11155: "Targeting the Jak2-GH receptor interaction for treatment of cancer", The Netherlands Proteomics Centre, "Proteomic analysis of

\section{REFERENCES}

1. Hershko A, Ciechanover A. The ubiquitin system for protein degradation. Annu Rev Biochem (1992) 61:761-807. doi: 10.1146/annurev.bi.61.070192.003553

2. Leung DW, Spencer SA, Cachianes G, Hammonds RG, Collins C, Henzel WJ, et al. Growth hormone receptor and serum binding protein: purification, cloning and expression. Nature (1987) 330:537-43. doi: 10.1038/330537a0

3. Strous GJ, van Kerkhof P, Govers R, Ciechanover A, Schwartz AL. The ubiquitin conjugation system is required for ligand-induced endocytosis and degradation of the growth hormone receptor. EMBO J (1996) 15:3806-12. doi: 10.1002/j.1460-2075.1996.tb00754.x

4. Basu R, Qian Y, Kopchick JJ. Mechanisms In Endocrinology: Lessons from growth hormone receptor gene-disrupted mice: are there benefits of endocrine defects? Eur J Endocrinol (2018) 178:R155-81. doi: 10.1530/EJE-18-0018

5. Ciechanover A. Intracellular protein degradation: From a vague idea thru the lysosome and the ubiquitin-proteasome system and onto human diseases and drug targeting. Best Pract Res Clin Haematol (2017) 30:341-55. doi: 10.1016/ j.beha.2017.09.001

6. Dehkhoda F, Lee CMM, Medina J, Brooks AJ. The Growth Hormone Receptor: Mechanism of Receptor Activation, Cell Signaling, and Physiological Aspects. Front Endocrinol (Lausanne) (2018) 9:35. doi: 10.3389/fendo.2018.00035

7. Foot N, Henshall T, Kumar S. Ubiquitination and the Regulation of Membrane Proteins. Physiol Rev (2017) 97:253-81. doi: 10.1152/physrev.00012.2016

8. Junnila RK, List EO, Berryman DE, Murrey JW, Kopchick JJ. The GH/IGF-1 axis in ageing and longevity. Nat Rev Endocrinol (2013) 9:366-76. doi: 10.1038/ nrendo.2013.67

9. Waters MJ. The growth hormone receptor. Growth Horm IGF Res (2016) 28:610. doi: 10.1016/j.ghir.2015.06.001

10. Wit JM, Oostdijk W, Losekoot M, van Duyvenvoorde HA, Ruivenkamp CA, Kant SG. Mechanisms In Endocrinology: Novel genetic causes of short stature. Eur J Endocrinol (2016) 174:R145-173. doi: 10.1530/EJE-15-0937

11. Guevara-Aguirre J, Guevara A, Palacios I, Perez M, Procel P, Teran E. GH and GHR signaling in human disease. Growth Horm IGF Res (2018) 38:34-8. doi: 10.1016/j.ghir.2017.12.006

12. Guevara-Aguirre J, Balasubramanian P, Guevara-Aguirre M, Wei M, Madia F, Cheng CW, et al. Growth hormone receptor deficiency is associated with a major reduction in pro-aging signaling, cancer, and diabetes in humans. Sci Transl Med (2011) 3:70ra13. doi: 10.1126/scitranslmed.3001845

13. Nashiro K, Guevara-Aguirre J, Braskie MN, Hafzalla GW, Velasco R, Balasubramanian P, et al. Brain Structure and Function Associated with Younger Adults in Growth Hormone Receptor-Deficient Humans. J Neurosci (2017) 37:1696-707. doi: 10.1523/JNEUROSCI.1929-16.2016

14. Posner BI, Kelly PA, Shiu RP, Friesen HG. Studies of insulin, growth hormone and prolactin binding: tissue distribution, species variation and characterization. Endocrinology (1974) 95:521-31. doi: 10.1210/endo-95-2-521

15. Kelly PA, Djiane J, Postel-Vinay MC, Edery M. The prolactin/growth hormone receptor family. Endocr Rev (1991) 12:235-51. doi: 10.1210/edrv-12-3-235

16. Godowski PJ, Leung DW, Meacham LR, Galgani JP, Hellmiss R, Keret R, et al. Characterization of the human growth hormone receptor gene and demonstration ubiquitylation in membrane trafficking, NPC3.1, and the Netherlands Organization for Scientific Research Grants NWO-ALW 814-02-011 and NWO-902-23-192.

\section{ACKNOWLEDGMENTS}

The authors thank all the collaborators who participated in the studies, in particular Peter van Kerkhof (UMC, Utrecht), Agnes van Rossum (Psychologie \& Coaching Praktijken, Utrecht), Marcel Roza (Genmab, Utrecht), Monique van den Eijnden, Elpetra Timmermans-Sprang (UU, Utrecht), and Lieke van der Velden (CBG, Utrecht).

of a partial gene deletion in two patients with Laron-type dwarfism. Proc Natl Acad Sci U.S.A. (1989) 86:8083-7. doi: 10.1073/pnas.86.20.8083

17. Boulay JL, O'Shea JJ, Paul WE. Molecular phylogeny within type I cytokines and their cognate receptors. Immunity (2003) 19:159-63. doi: 10.1016/S10747613(03)00211-5

18. Bagley CJ, Woodcock JM, Stomski FC, Lopez AF. The structural and functional basis of cytokine receptor activation: lessons from the common á subunit of the granulocyte-macrophage colony-stimulating factor, interleukin-3 (il-3), and il-5 recept. Blood (1997) 89:1471-82. 1471-1482. doi: 10.1182/blood.V89.5.1471.1471_1471_1482

19. Baumgartner JW, Wells CA, Chen CM, Waters MJ. The role of the WSXWS equivalent motif in growth hormone receptor function. J Biol Chem (1994) 269:29094-101.

20. de Vos AM, Ultsch M, Kossiakoff AA. Human growth hormone and extracellular domain of its receptor: crystal structure of the complex. Science (1992) 255:306-12. doi: 10.1126/science.1549776

21. Chhabra Y, Wong HY, Nikolajsen LF, Steinocher H, Papadopulos A, Tunny $\mathrm{KA}$, et al. A growth hormone receptor SNP promotes lung cancer by impairment of SOCS2-mediated degradation. Oncogene (2018) 37:489-501. doi: 10.1038 /onc. 2017.352

22. Putters J. Phosphorylation and Ubiquitination in Growth Hormone Receptor Endocytosis and Signalling, Chapter $V$, The contribution of tyrosine residues to growth hormone receptor signalling. Thesis, Utrecht: Utrecht University (2010). Available at: http://dspace.library.uu.nl/handle/1874/396613.

23. Fuh G, Mulkerrin MG, Bass S, McFarland N, Brochier M, Bourell JH, et al. The human growth hormone receptor. Secretion from Escherichia Coli and disulphide bonding pattern of the extracellular domain. J Biol Chem (1990) 265:3111-5.

24. Sedek M. Posttranslational modifications of the regulation of GHR and Jak2. Chapter V: SUMO2/3 regulates GHR trafficking. Thesis, Utrecht: Utrecht University (2012). Available at: https://dspace.library.uu.nl/handle/1874/397232.

25. Conway-Campbell BL, Wooh JW, Brooks AJ, Gordon D, Brown RJ, Lichanska $\mathrm{AM}$, et al. Nuclear targeting of the growth hormone receptor results in dysregulation of cell proliferation and tumorigenesis. Proc Natl Acad Sci U S A (2007) 104:13331-6. doi: 10.1073/pnas.0600181104

26. Waters MJ, Brooks AJ. Growth hormone and cell growth. Endocr Dev (2012) 23:86-95. doi: 10.1159/000341761

27. Sedek M, van der Velden LM, Strous GJ. Multimeric growth hormone receptor complexes serve as signaling platforms. J Biol Chem (2014) 289:65-73. doi: 10.1074/jbc.M113.523373

28. Liu Y, Zhang Y, Jiang J, Lobie PE, Paulmurugan R, Langenheim JF, et al. GHR/ PRLR Heteromultimer Is Composed of GHR Homodimers and PRLR Homodimers. Mol Endocrinol (2016) 30:504-17. doi: 10.1210/me.2015-1319

29. Gent J, van Kerkhof P, Roza M, Bu G, Strous GJ. Ligand-independent growth hormone receptor dimerization occurs in the endoplasmic reticulum and is required for ubiquitin system-dependent endocytosis. Proc Natl Acad Sci U S A (2002) 99:9858-63. doi: 10.1073/pnas.152294299

30. Schantl JA, Roza M, de Jong AP, Strous GJ. Small glutamine-rich tetratricopeptide repeat-containing protein interacts with the ubiquitin-dependent endocytosis 
motif of the growth hormone receptor. Biochem J (2003) 373:855-63. doi: 10.1042/ bj20021591

31. Schantl JA. Growth Hormone Receptor Interacting Proteins, Chapter III: The anti-apoptotic protein Scythe interacts with the ubiquitin-dependent endocytosis motif of the growth hormone receptor and localizes to mitochondria. Thesis, Utrecht: Utrecht University (2003). Available at: http://dspace.library.uu.nl/handle/1874/396614.

32. Benarroch R, Austin JM, Ahmed F, Isaacson RL. The roles of cytosolic quality control proteins, SGTA and the BAG6 complex, in disease. Adv Protein Chem Struct Biol (2019) 114:265-313. doi: 10.1016/bs.apcsb.2018.11.002

33. Shao S, Rodrigo-Brenni MC, Kivlen MH, Hegde RS. Mechanistic basis for a molecular triage reaction. Science (2017) 355:298-302. doi: 10.1126/ science.aah6130

34. Leznicki P, Korac-Prlic J, Kliza K, Husnjak K, Nyathi Y, Dikic I, et al. Binding of SGTA to Rpn13 selectively modulates protein quality control. J Cell Sci (2015) 128:3187-96. doi: 10.1242/jcs.165209

35. Slotman JA, van Kerkhof P, Hassink GC, Kuiken HJ, Strous GJ. Identification of Ubiquitin System Factors in Growth Hormone Receptor Transport. In: In Tech, Molecular Regulation of Endocytosis, vol. 15. London: IntechOpen Limited, London, UK (2012). p. 391-410. 391-410.

36. Gent J, Van Den Eijnden M, Van Kerkhof P, Strous GJ. Dimerization and signal transduction of the growth hormone receptor. Mol Endocrinol (2003) 17:967-75. doi: 10.1210/me.2002-0261

37. Amit T, Hartmann K, Shoshany G, Baruch Y, Youdim MBH, Hochberg Z. The turnover of growth hormone (gh)-binding protein and gh receptor in rabbit and rat. Mol Cell Endocrinol (1993) 94:149-54. doi: 10.1016/0303-7207 (93) $90163-\mathrm{E}$

38. Murphy LJ, Lazarus L. The mouse fibroblast growth hormone receptor: ligand processing and receptor modulation and turnover. Endocrinology (1984) 115:1625-32. doi: 10.1210/endo-115-4-1625

39. van Kerkhof P, Smeets M, Strous GJ. The ubiquitin-proteasome pathway regulates the availability of the GH receptor. Endocrinology (2002) 143:124352. doi: 10.1210/endo.143.4.8755

40. Govers R, van Kerkhof P, Schwartz AL, Strous GJ. Linkage of the ubiquitinconjugating system and the endocytic pathway in ligand-induced internalization of the growth hormone receptor. EMBO J (1997) 16:48518.internalization of the growth hormone receptor. Embo J 1997, 16:4851-4858. doi: 10.1093/emboj/16.16.4851

41. van Kerkhof P, Sachse M, Klumperman J, Strous GJ. Growth hormone receptor ubiquitination coincides with recruitment to clathrin-coated membrane domains. J Biol Chem (2000) 276:3778-84. doi: 10.1074/ jbc.M007326200

42. da Silva Almeida AC, Strous GJ, van Rossum AG. betaTrCP controls GH receptor degradation via two different motifs. Mol Endocrinol (2012) 26:16577. doi: 10.1210/me.2011-1211

43. van Kerkhof P, Alves dos Santos CM, Sachse M, Klumperman J, Bu G, Strous GJ. Proteasome inhibitors block a late step in lysosomal transport of selected membrane but not soluble proteins. Mol Biol Cell (2001) 12:2556-66. doi: $10.1091 / \mathrm{mbc} .12 .8 .2556$

44. Sotiropoulos A, Goujon L, Simonin G, Kelly PA, PostelVinay MC, Finidori J. Evidence for generation of the growth hormone-binding protein through proteolysis of the growth hormone membrane receptor. Endocrinology (1993) 132:1863-5. doi: 10.1210/endo.132.4.8462483

45. Zhang Y, Jiang J, Black RA, Baumann G, Frank SJ. Tumor necrosis factoralpha converting enzyme (TACE) is a growth hormone binding protein (GHBP) sheddase: the metalloprotease TACE/ADAM-17 is critical for (PMA-induced) GH receptor proteolysis and GHBP generation. Endocrinology (2000) 141:4342-8. doi: 10.1210/endo.141.12.7858

46. Amit T, Youdim MB, Hochberg Z. Clinical review 112: Does serum growth hormone (GH) binding protein reflect human GH receptor function? J Clin Endocrinol Metab (2000) 85:927-32. doi: 10.1210/jcem.85.3.6461

47. Zhang JG, Metcalf D, Rakar S, Asimakis M, Greenhalgh CJ, Willson TA. et al: The SOCS box of suppressor of cytokine signaling-1 is important for inhibition of cytokine action invivo. Proc Natl Acad Sci U.S.A. (2001) 98:13261-5. doi: 10.1073/pnas.231486498

48. Conte F, Salles JP, Raynal P, Fernandez L, Molinas C, Tauber M, et al. Identification of a region critical for proteolysis of the human growth hormone receptor. Biochem Biophys Res Commun (2002) 290:851-7. doi: $10.1006 /$ bbrc. 2001.6261

49. Baumann G. Growth hormone binding protein 2001. J Pediatr Endocrinol Metab (2001) 14:355-75. doi: 10.1515/JPEM.2001.14.4.355

50. Strous GJ, van Kerkhof P. The ubiquitin-proteasome pathway and the regulation of growth hormone receptor availability. Mol Cell Endocrinol (2002) 197:143-51. doi: 10.1016/S0303-7207(02)00258-7

51. Kawauchi H, Sower SA. The dawn and evolution of hormones in the adenohypophysis. Gen Comp Endocrinol (2006) 148:3-14. doi: 10.1016/ j.ygcen.2005.10.011

52. Baumann G. Growth hormone heterogeneity: genes, isohormones, variants, and binding proteins. Endocrine Rev (1991) 12:424-49. doi: 10.1210/edrv-12-4-424

53. Okada S, Kopchick JJ. Biological effects of growth hormone and its antagonist. Trends Mol Med (2001) 7:126-32. doi: 10.1016/S1471-4914(01)01933-5

54. Harvey S. Extrapituitary growth hormone. Endocrine (2010) 38:335-59. doi: 10.1007/s12020-010-9403-8

55. Harvey S, Martinez-Moreno CG, Luna M, Aramburo C. Autocrine/paracrine roles of extrapituitary growth hormone and prolactin in health and disease: An overview. Gen Comp Endocrinol (2015) 220:103-11. doi: 10.1016/ j.ygcen.2014.11.004

56. Mol JA, Lantinga-van Leeuwen IS, van Garderen E, Selman PJ, OosterlakenDijksterhuis MA, Schalken JA, et al. Mammary growth hormone and tumorigenesis-lessons from the dog. Vet $Q$ (1999) 21:111-5. doi: 10.1080/ 01652176.1999 .9695004

57. Lombardi S, Honeth G, Ginestier C, Shinomiya I, Marlow R, Buchupalli B. et al: Growth hormone is secreted by normal breast epithelium upon progesterone stimulation and increases proliferation of stem/progenitor cells. Stem Cell Rep (2014) 2:780-93. doi: 10.1016/j.stemcr.2014.05.005

58. Timmermans-Sprang EPM, Gracanin A, Mol JA. Molecular Signaling of Progesterone, Growth Hormone, Wnt, and HER in Mammary Glands of Dogs, Rodents, and Humans: New Treatment Target Identification. Front Vet Sci (2017) 4:53. doi: 10.3389/fvets.2017.00053

59. Goffin V, Shiverick KT, Kelly PA, Martial JA. Sequence-function relationships within the expanding family of prolactin, growth hormone, placental lactogen, and related proteins in mammals. Endocr Rev (1996) 17:385-410. doi: 10.1210/er.17.4.385

60. Besson A, Salemi S, Deladoey J, Vuissoz JM, Eble A, Bidlingmaier M, et al. Short stature caused by a biologically inactive mutant growth hormone $(\mathrm{GH}-$ C53S). J Clin Endocrinol Metab (2005) 90:2493-9. doi: 10.1210/jc.2004-1838

61. Ranke MB, Wit JM. Growth hormone - past, present and future. Nat Rev Endocrinol (2018) 14:285-300. doi: 10.1038/nrendo.2018.22

62. Hartman ML, Faria AC, Vance ML, Johnson ML, Thorner MO, Veldhuis JD. Temporal structure of in vivo growth hormone secretory events in humans. Am J Physiol (1991) 260:E101-110. doi: 10.1152/ajpendo.1991.260.1.E101

63. Ho KY, Veldhuis JD, Johnson ML, Furlanetto R, Evans WS, Alberti KG. et al: Fasting enhances growth hormone secretion and amplifies the complex rhythms of growth hormone secretion in man. J Clin Invest (1988) 81:96875. doi: 10.1172/JCI113450

64. Takahashi Y, Kipnis DM, Daughaday WH. Growth hormone secretion during sleep. J Clin Invest (1968) 47:2079-90. doi: 10.1172/JCI105893

65. Choi HK, Waxman DJ. Pulsatility of growth hormone (GH) signalling in liver cells: role of the JAK-STAT5b pathway in GH action. Growth Horm IGF Res (2000) 10 Suppl B:S1-8. doi: 10.1016/S1096-6374(00)80002-7

66. Gustafsson JA, Mode A, Norstedt G, Skett P. Sex steroid induced changes in hepatic enzymes. Annu Rev Physiol (1983) 45:51-60. doi: 10.1146/ annurev.ph.45.030183.000411

67. Norstedt G, Palmiter R. Secretory rhythm of growth hormone regulates sexual differentiation of mouse liver. Cell (1984) 36:805-12. doi: 10.1016/0092-8674 (84) $90030-8$

68. Clodfelter KH, Holloway MG, Hodor P, Park SH, Ray WJ, Waxman DJ. Sexdependent liver gene expression is extensive and largely dependent upon signal transducer and activator of transcription 5b (STAT5b): STAT5bdependent activation of male genes and repression of female genes revealed by microarray analysis. Mol Endocrinol (2006) 20:1333-51. doi: 10.1210/ me.2005-0489

69. Laz EV, Sugathan A, Waxman DJ. Dynamic in vivo binding of STAT5 to growth hormone-regulated genes in intact rat liver. Sex-specific binding at 
low- but not high-affinity STAT5 sites. Mol Endocrinol (2009) 23:1242-54. doi: 10.1210/me.2008-0449

70. Zhang Y, Laz EV, Waxman DJ. Dynamic, sex-differential STAT5 and BCL6 binding to sex-biased, growth hormone-regulated genes in adult mouse liver. Mol Cell Biol (2012) 32:880-96. doi: 10.1128/MCB.06312-11

71. Chen C. Growth hormone secretagogue actions on the pituitary gland: multiple receptors for multiple ligands? Clin Exp Pharmacol Physiol (2000) 27:323-9. doi: 10.1046/j.1440-1681.2000.03258.x

72. Kojima M, Hosoda H, Date Y, Nakazato M, Matsuo H, Kangawa K. Ghrelin is a growth-hormone-releasing acylated peptide from stomach. Nature (1999) 402:656-60. doi: 10.1038/45230

73. Hartman ML, Clayton PE, Johnson ML, Celniker A, Perlman AJ, Alberti KG, et al. A low dose euglycemic infusion of recombinant human insulin-like growth factor I rapidly suppresses fasting-enhanced pulsatile growth hormone secretion in humans. J Clin Invest (1993) 91:2453-62.91:2453-2462. doi: 10.1172/JCI1 16480

74. Pellegrini I, Roche C, Quentien MH, Ferrand M, Gunz G, Thirion S, et al. Involvement of the pituitary-specific transcription factor pit-1 in somatolactotrope cell growth and death: an approach using dominantnegative pit-1 mutants. Mol Endocrinol (2006) 20:3212-27. doi: 10.1210/ me.2006-0122

75. Andersen B, Rosenfeld MG. Pit-1 determines cell types during development of the anterior pituitary gland. A model for transcriptional regulation of cell phenotypes in mammalian organogenesis. J Biol Chem (1994) 269:29335-8.

76. Roth J, Glick SM, Yalow RS, Berson SA. Secretion of human growth hormone: physiologic and experimental modification. Metabolism (1963) 12:577-9.

77. Hansen AP. Abnormal serum growth hormone response to exercise in maturityonset diabetics. Diabetes (1973) 22:619-28. doi: 10.2337/diab.22.8.619

78. Melmed S, Polonsky KS, Larsen PR, H. K. Williams Textbook of Endocrinology. Philadelphia: Elsevier (2015).

79. Veldhuis JD, Roemmich JN, Richmond EJ, Bowers CY. Somatotropic and gonadotropic axes linkages in infancy, childhood, and the puberty-adult transition. Endocr Rev (2006) 27:101-40. doi: 10.1210/er.2005-0006

80. Corpas E, Harman SM, Blackman MR. Human growth hormone and human aging. Endocr Rev (1993) 14:20-39. doi: 10.1210/edrv-14-1-20

81. McIntyre HD, Zeck W, Russell A. Placental growth hormone, fetal growth and the IGF axis in normal and diabetic pregnancy. Curr Diabetes Rev (2009) 5:185-9. doi: 10.2174/157339909788920947

82. van den Eijnden MJ, Strous GJ. Autocrine growth hormone: effects on growth hormone receptor trafficking and signaling. Mol Endocrinol (2007) 21:283246. doi: 10.1210/me.2007-0092

83. Firmbach-Kraft I, Byers M, Shows T, Dalla-Favera R, Krolewski JJ. tyk2, prototype of a novel class of non-receptor tyrosine kinase genes. Oncogene (1990) 5:1329-36.

84. Argetsinger LS, Campbell GS, Yang XN, Witthuhn BA, Silvennoinen O, Ihle $\mathrm{JN}$, et al. Identification of JAK2 as a growth hormone receptor-associated tyrosine kinase. Cell (1993) 74:237-44. doi: 10.1016/0092-8674(93)90415-M

85. Rowlinson SW, Yoshizato H, Barclay JL, Brooks AJ, Behncken SN, Kerr LM, et al. An agonist-induced conformational change in the growth hormone receptor determines the choice of signalling pathway. Nat Cell Biol (2008) 10:740-7. doi: $10.1038 / \mathrm{ncb} 1737$

86. Frank SJ. Classical and novel GH receptor signaling pathways. Mol Cell Endocrinol (2020) 518:110999. doi: 10.1016/j.mce.2020.110999

87. Brown RJ, Adams JJ, Pelekanos RA, Wan Y, McKinstry WJ, Palethorpe K. et al: Model for growth hormone receptor activation based on subunit rotation within a receptor dimer. Nat Struct Mol Biol (2005) 12:814-21. doi: 10.1038/nsmb977

88. Waters MJ, Brooks AJ. JAK2 activation by growth hormone and other cytokines. Biochem J (2015) 466:1-11. doi: 10.1042/BJ20141293

89. Brooks AJ, Dai W, O'Mara ML, Abankwa D, Chhabra Y, Pelekanos RA. et al: Mechanism of activation of protein kinase JAK2 by the growth hormone receptor. Science (2014) 344:1249783. doi: 10.1126/science.1249783

90. Wilmes S, Hafer M, Vuorio J, Tucker JA, Winkelmann H, Lochte S. et al: Mechanism of homodimeric cytokine receptor activation and dysregulation by oncogenic mutations. Science (2020) 367:643-52. doi: 10.1126/ science.aaw3242

91. Carter-Su C, Schwartz J, Argetsinger LS. Growth hormone signaling pathways. Growth Horm IGF Res (2016) 28:11-5. doi: 10.1016/j.ghir.2015.09.002
92. Putters J, da Silva Almeida AC, van Kerkhof P, van Rossum AG, Gracanin A, Strous GJ. Jak2 is a negative regulator of ubiquitin-dependent endocytosis of the growth hormone receptor. PloS One (2011) 6:e14676. doi: 10.1371/ journal.pone. 0014676

93. Frank SJ, Yi W, Zhao Y, Goldsmith JF, Gilliland G, Jiang J, et al. Regions of the JAK2 tyrosine kinase required for coupling to the growth hormone receptor. J Biol Chem (1995) 270:14776-85. doi: 10.1074/jbc.270.24.14776

94. Saharinen P, Vihinen M, Silvennoinen O. Autoinhibition of Jak2 tyrosine kinase is dependent on specific regions in its pseudokinase domain. Mol Biol Cell (2003) 14:1448-59. doi: 10.1091/mbc.e02-06-0342

95. Lacronique V, Boureux A, Valle VD, Poirel H, Quang CT, Mauchauffe M, et al. A TEL-JAK2 fusion protein with constitutive kinase activity in human leukemia. Science (1997) 278:1309-12. doi: 10.1126/science.278.5341.1309

96. Kralovics R, Passamonti F, Buser AS, Teo SS, Tiedt R, Passweg JR, et al. A gain-of-function mutation of JAK2 in myeloproliferative disorders. $\mathrm{N} \mathrm{Engl} \mathrm{J}$ Med (2005) 352:1779-90. doi: 10.1056/NEJMoa051113

97. Lee TS, Ma W, Zhang X, Giles F, Kantarjian H, Albitar M. Mechanisms of constitutive activation of Janus kinase 2-V617F revealed at the atomic level through molecular dynamics simulations. Cancer (2009) 115:1692-700. doi: $10.1002 / \mathrm{cncr} .24183$

98. Zhao L, Dong H, Zhang CC, Kinch L, Osawa M, Iacovino M, et al. A JAK2 interdomain linker relays Epo receptor engagement signals to kinase activation. J Biol Chem (2009) 284:26988-98. doi: 10.1074/jbc.M109.011387

99. Feng J, Witthuhn BA, Matsuda T, Kohlhuber F, Kerr IM, Ihle JN. Activation of Jak2 catalytic activity requires phosphorylation of Y1007 in the kinase activation loop. Mol Cell Biol (1997) 17:2497-501. doi: 10.1128/ MCB.17.5.2497

100. Funakoshi-Tago M, Pelletier S, Matsuda T, Parganas E, Ihle JN. Receptor specific downregulation of cytokine signaling by autophosphorylation in the FERM domain of Jak2. EMBO J (2006) 25:4763-72. doi: 10.1038/ sj.emboj.7601365

101. Kurzer JH, Argetsinger LS, Zhou YJ, Kouadio JL, O'Shea JJ, Carter-Su C. Tyrosine 813 Is a Site of JAK2 Autophosphorylation Critical for Activation of JAK2 by SH2-Bbeta Influence of growth hormone on the mandibular condylar cartilage of rats. Mol Cell Biol (2004) 24:4557-70. doi: 10.1128/ MCB.24.10.4557-4570.2004

102. Argetsinger LS, Kouadio JL, Steen H, Stensballe A, Jensen ON, Carter-Su C. Autophosphorylation of JAK2 on Tyrosines 221 and 570 Regulates Its Activity. Mol Cell Biol (2004) 24:4955-67. doi: 10.1128/MCB.24.11.49554967.2004

103. Nespital T, Strous GJ. The Jak/STAT signaling pathway is downregulated at febrile temperatures. PloS One (2012) 7:e49374. doi: 10.1371/ journal.pone.0049374

104. Ungureanu D, Saharinen P, Junttila I, Hilton DJ, Silvennoinen O. Regulation of Jak2 through the Ubiquitin-Proteasome Pathway Involves Phosphorylation of Jak2 on Y1007 and Interaction with SOCS-1. Mol Cell Biol (2002) 22:3316-26.doi: 10.1128/MCB.22.10.3316-3326.2002

105. Zhu T, Ling L, Lobie PE. Identification of a JAK2 independent pathway regulating growth hormone $(\mathrm{GH})$ stimulated p44/42 MAP kinase activity: GH activation of RAL and phospholipase D is Src dependent. J Biol Chem (2002) 277:45592-603. doi: 10.1074/jbc.M201385200

106. Barclay JL, Kerr LM, Arthur L, Rowland JE, Nelson CN, Ishikawa M, et al. In vivo targeting of the growth hormone receptor (GHR) Boxl sequence demonstrates that the GHR does not signal exclusively through JAK2. Mol Endocrinol (2010) 24:204-17. doi: 10.1210/me.2009-0233

107. Ishikawa M, Brooks AJ, Fernandez-Rojo MA, Medina J, Chhabra Y, Minam $S$, et al. Growth hormone stops excessive inflammation after partial hepatectomy allowing liver regeneration and survival via induction of $\mathrm{H} 2$ Bl/HLA-G. Hepatology (2020) 258:119-133. doi: 10.1002/hep.31297

108. Jin H, Lanning NJ, Carter-Su C. JAK2, but Not Src Family Kinases, is Required for STAT, ERK and Akt Signaling in Response to Growth Hormone in Preadipocytes and Hepatoma Cells. Mol Endocrinol (2008) 22:1825-41. doi: 10.1210/me.2008-0015

109. Ben-Avraham D, Govindaraju DR, Budagov T, Fradin D, Durda P, Liu B. et al: The GH receptor exon 3 deletion is a marker of male-specific exceptional longevity associated with increased GH sensitivity and taller stature. Sci $A d v$ (2017) 3:e1602025. doi: 10.1126/sciadv.1602025 
110. Ihle JN. The Stat family in cytokine signaling. Curr Opin Cell Biol (2001) 13:211-7. doi: 10.1016/S0955-0674(00)00199-X

111. Chatterjee-Kishore M, van den Akker F, Stark GR. Association of STATs with relatives and friends. Trends Cell Biol (2000) 10:106-11. doi: 10.1016/ S0962-8924(99)01709-2

112. Herrington J, Smit LS, Schwartz J, CarterSu C. The role of STAT proteins in growth hormone signaling. Oncogene (2000) 19:2585-97. doi: 10.1038/ sj.onc. 1203526

113. Waxman DJ, O'Connor C. Growth Hormone Regulation of Sex-dependent Liver Gene Expression*. Mol Endocrinol (2006) 20:2613-29. doi: 10.1210/ me.2006-0007

114. Lau-Corona D, Bae WK, Hennighausen L, Waxman DJ. Sex-biased genetic programs in liver metabolism and liver fibrosis are controlled by EZH1 and EZH2. PloS Genet (2020) 16:e1008796. doi: 10.1371/journal.pgen.1008796

115. Woelfle J, Chia DJ, Rotwein P. Mechanisms of growth hormone action: identification of conserved Stat5 binding sites that mediate GH-induced insulin-like growth factor-I gene activation. J Biol Chem (2003) 278:51261-6. doi: 10.1074/jbc.M309486200

116. Rotwein P. Regulation of gene expression by growth hormone. Mol Cell Endocrinol (2020), 57:110788. doi: 10.1016/j.mce.2020.110788

117. Rosenfeld RG, Kofoed E, Buckway C, Little B, Woods KA, Tsubaki J, et al. Identification of the first patient with a confirmed mutation of the JAK-STAT system. Pediatr Nephrol (2005) 20:303-5. doi: 10.1007/s00467-004-1678-7

118. Klammt J, Neumann D, Gevers EF, Andrew SF, Schwartz ID, Rockstroh D, et al. Dominant-negative STAT5B mutations cause growth hormone insensitivity with short stature and mild immune dysregulation. Nat Commun (2018) 9:2105. doi: 10.1038/s41467-018-04521-0

119. Yi WS, Kim SO, Jiang J, Park SH, Kraft AS, Waxman DJ, et al. Growth hormone receptor cytoplasmic domain differentially promotes tyrosine phosphorylation of signal transducers and activators of transcription $5 \mathrm{~b}$ and 3 by activated JAK2 kinase. MolEndocrinol (1996) 10:1425-43. doi: 10.1210/me.10.11.1425

120. Hansen LH, Wang X, Kopchick JJ, Bouchelouche P, Nielsen JH, Galsgaard $\mathrm{ED}$, et al. Identification of tyrosine residues in the intracellular domain of the growth hormone receptor required for transcriptional signaling and Stat5 activation. J Biol Chem (1996) 271:12669-73. doi: 10.1074/jbc.271.21.12669

121. Smit LS, Meyer DJ, Billestrup N, Norstedt G, Schwartz J, Carter-Su C. The role of the growth hormone $(\mathrm{GH})$ receptor and Jak1 and Jak2 kinases in the activation of stats 1,3, and 5 by GH. Mol Endocrinol (1996) 10:519-33. doi: 10.1210/mend.10.5.8732683

122. Thirone ACP, Carvalho CRO, Saad MJA. Growth hormone stimulates the tyrosine kinase activity of JAK2 and induces tyrosine phosphorylation of insulin receptor substrates and Shc in rat tissues. Endocrinology (1999) 140:55-62. doi: 10.1210/endo.140.1.6417

123. Vanderkuur JA, Butch ER, Waters SB, Pessin JE, Guan KL, Carter-Su C. Signaling molecules involved in coupling growth hormone receptor to mitogen-activated protein kinase activation. Endocrinology (1997) 138:4301-7. doi: 10.1210/endo.138.10.5453

124. Frank SJ. Growth hormone signalling and its regulation: Preventing too much of a good thing. Growth Horm IGF Res (2001) 11:201-12. doi: 10.1054/ ghir.2001.0237

125. Decker T, Kovarik P. Serine phosphorylation of STATs. Oncogene (2000) 19:2628-37. doi: 10.1038/sj.onc.1203481

126. Pircher TJ, Petersen H, Gustafsson JA, Haldosen LA. Extracellular signalregulated kinase (ERK) interacts with signal transducer and activator of transcription (STAT) 5a. Mol Endocrinol (1999) 13:555-65. doi: 10.1210/ mend.13.4.0263

127. Yamauchi T, Ueki K, Tobe K, Tamemoto H, Sekine N, Wada M, et al. Tyrosine phosphorylation of the EGF receptor by the kinase Jak2 is induced by growth hormone. Nature (1997) 390:91-6. doi: 10.1038/36369

128. Kim SO, Houtman JCD, Jiang J, Ruppert JI, Bertics PJ, Frank SJ. Growth hormone-induced alteration in ErbB-2 phosphorylation status in 3T3F442A fibroblasts. J Biol Chem (1999) 274:36015-24. doi: 10.1074/ jbc.274.50.36015

129. Zhu T, Lobie PE. Janus kinase 2-dependent activation of p38 mitogenactivated protein kinase by growth hormone. Resultant transcriptional activation of ATF-2 and CHOP, cytoskeletal re-organization and mitogenesis. J Biol Chem (2000) 275:2103-14. doi: 10.1074/jbc.275.3.2103
130. Zhu T, Goh ELK, Leroith D, Lobie PE. Growth hormone stimulates the formation of a multiprotein signaling complex involving p130(Cas) and CrkII - Resultant activation of c-Jun N-terminal kinase/stressactivatedprotein kinase (JNK/SAPK). J Biol Chem (1998) 273:33864-75. doi: $10.1074 / \mathrm{jbc} .273 .50 .33864$

131. Yamauchi T, Kaburagi Y, Ueki K, Tsuji Y, Stark GR, Kerr IM, et al. Growth hormone and prolactin stimulate tyrosine phosphorylation of insulin receptor substrate-1, -2 , and -3 , their association with p85 phosphatidylinositol 3-kinase (PI3-kinase), and concomitantly PI3-kinase activation via JAK2 kinase. J Biol Chem (1998) 273:15719-26. doi: 10.1074/ jbc.273.25.15719

132. Yokota I, Hayashi H, Matsuda J, Saijo T, Naito E, Ito M, et al. Effect of growth hormone on the translocation of GLUT4 and its relation to insulin-like and anti-insulin action. Biochim Biophys Acta - Mol Cell Res (1998) 1404:451-6. doi: 10.1016/S0167-4889(98)00077-9

133. Ridderstrale M, Tornqvist H. PI-3-kinase inhibitor Wortmannin blocks the insulin-like effects of growth hormone in isolated rat adipocytes. Biochem Biophys Res Commun (1994) 203:306-10. doi: 10.1006/bbrc.1994.2182

134. Ridderstrale M. Signaling mechanism for the insulin-like effects of growth hormone-another example of a classical hormonal negative feedback loop. Curr Drug Targets Immune Endocr Metabol Disord (2005) 5:79-92. doi: $10.2174 / 1568008053174787$

135. Costoya JA, Finidori J, Moutoussamy S, Searis R, Devesa J, Arce VM. Activation of growth hormone receptor delivers an antiapoptotic signal: evidence for a role of Akt in this pathway. Endocrinology (1999) 140:593743. doi: 10.1210/endo.140.12.7209

136. MacKenzie SJ, Yarwood SJ, Peden AH, Bolger GB, Vernon RG, Houslay MD. Stimulation of p70S6 kinase via a growth hormone-controlled phosphatidylinositol 3-kinase pathway leads to the activation of a PDE4A cyclic AMP-specific phosphodiesterase in 3T3-F442A preadipocytes. Proc Nat Acad Sci USA (1998) 95:3549-54. doi: 10.1073/pnas.95.7.3549

137. Jeay S, Sonenshein GE, Postel-Vinay MC, Kelly PA, Baixeras E. Growth hormone can act as a cytokine controlling survival and proliferation of immune cells: new insights into signaling pathways. Mol Cell Endocrinol (2002) 188:1-7. doi: 10.1016/S0303-7207(02)00014-X

138. Flores-Morales A, Greenhalgh CJ, Norstedt G, Rico-Bautista E. Negative Regulation of Growth Hormone Receptor Signaling. Mol Endocrinol (2006) 20:241-53. doi: 10.1210/me.2005-0170

139. Hackett RH, Wang YD, Sweitzer S, Feldman G, Wood WI, Larner AC. Mapping of a cytoplasmic domain of the human growth hormone receptor that regulates rates of inactivation of jak2 and stat proteins. J Biol Chem (1997) 272:11128-32. doi: 10.1074/jbc.272.17.11128

140. Kim SO, Jiang J, Yi W, Feng GS, Frank SJ. Involvement of the Src homology 2-containing tyrosine phosphatase SHP-2 in growth hormone signaling. J Biol Chem (1998) 273:2344-54. doi: 10.1074/jbc.273.4.2344

141. Stofega MR, Herrington J, Billestrup N, Carter-Su C. Mutation of the SHP-2 binding site in growth hormone $(\mathrm{GH})$ receptor prolongs $\mathrm{GH}$-promoted tyrosyl phosphorylation of GH receptor, JAK2, and STAT5B. Mol Endocrinol (2000) 14:1338-50. doi: 10.1210/mend.14.9.0513

142. Stofega MR, Argetsinger LS, Wang H, Ullrich A, Carter-Su C. Negative regulation of growth hormone receptor/JAK2 signaling by signal regulatory protein alpha. J Biol Chem (2000) 275:28222-9. doi: 10.1074/ jbc.M004238200

143. Pasquali C, Curchod ML, Walchli S, Espanel X, Guerrier M, Arigoni F, et al. Identification of Protein Tyrosine Phosphatases with specificity for the ligand-activated GH Receptor. Mol Endocrinol (2003) 17:2228-39. doi: 10.1210/me.2003-0011

144. Gu F, Dube N, Kim JW, Cheng A, Ibarra-Sanchez Md Mde J, Tremblay ML, et al. Protein Tyrosine Phosphatase 1B Attenuates Growth HormoneMediated JAK2-STAT Signaling. Mol Cell Biol (2003) 23:3753-62. doi: 10.1128/MCB.23.11.3753-3762.2003

145. Pilecka I, Whatmore A, Hooft van Huijsduijnen R, Destenaves B, Clayton P. Growth hormone signalling: sprouting links between pathways, human genetics and therapeutic options. Trends Endocrinol Metab (2007) 18:12-8. doi: 10.1016/j.tem.2006.11.004

146. Irie-Sasaki J, Sasaki T, Matsumoto W, Opavsky A, Cheng M, Welstead G, et al. CD45 is a JAK phosphatase and negatively regulates cytokine receptor signalling. Nature (2001) 409:349-54. doi: 10.1038/35053086 
147. Rakesh K, Agrawal DK. Controlling cytokine signaling by constitutive inhibitors. Biochem Pharmacol (2005) 70:649-57. doi: 10.1016/ j.bcp.2005.04.042

148. Moutoussamy S, Renaudie F, Lago F, Kelly PA, Finidori J. Grb10 identified as a potential regulator of growth hormone $(\mathrm{GH})$ signaling by cloning of $\mathrm{GH}$ receptor target proteins. J Biol Chem (1998) 273:15906-12. doi: 10.1074/ jbc.273.26.15906

149. Rui L, Carter-Su C. Identification of SH2-bbeta as a potent cytoplasmic activator of the tyrosine kinase Janus kinase 2. Proc Natl Acad Sci U.S.A. (1999) 96:7172-7. doi: 10.1073/pnas.96.13.7172

150. Birzniece V, Sata A, Ho KK. Growth hormone receptor modulators. Rev Endocr Metab Disord (2009) 10:145-56. doi: 10.1007/s11154-008-9089-x

151. von Laue S, Ross RJ. Inflammatory cytokines and acquired growth hormone resistance. Growth Horm IGF Res (2000) 10 Suppl B:S9-14. doi: 10.1016/ S1096-6374(00)80003-9

152. Zhang Y, Guan R, Jiang J, Kopchick JJ, Black RA, Baumann G. et al: Growth hormone (GH)-induced dimerization inhibits phorbol ester-stimulated GH receptor proteolysis. J Biol Chem (2001) 276:24565-73. doi: 10.1074/ jbc.M101281200

153. Loesch K, Deng L, Cowan JW, Wang X, He K, Jiang J. et al: Janus Kinase 2 Influences Growth Hormone Receptor Metalloproteolysis. Endocrinology (2006) 147:2839-49. doi: 10.1210/en.2005-1484

154. Sawyer ST, Hankins WD. The functional form of the erythropoietin receptor is a 78-kDa protein: correlation with cell surface expression, endocytosis, and phosphorylation. Proc Natl Acad Sci U.S.A. (1993) 90:6849-53. doi: 10.1073/ pnas.90.14.6849

155. Genty N, Paly J, Edery M, Kelly PA, Djiane J, Salesse R. Endocytosis and degradation of prolactin and its receptor in Chinese hamster ovary cells stably transfected with prolactin receptor cDNA. Mol Cell Endocrinol (1994) 99:221-8. doi: 10.1016/0303-7207(94)90011-6

156. Hurley JH, Stenmark H. Molecular Mechanisms of Ubiquitin-Dependent Membrane Traffic. Annu Rev Biophys (2011) 40:119-42. doi: 10.1146/ annurev-biophys-042910-155404

157. Kölling R, Hollenberg CP. The ABC-transpporter Ste6 accumulates in the plasma membrane in a ubiquitinated form in endocytosis mutants. EMBO J (1994) 13:3261-71. doi: 10.1002/j.1460-2075.1994.tb06627.x

158. Critchley WR, Pellet-Many C, Ringham-Terry B, Harrison MA, Zachary IC, Ponnambalam S. Receptor Tyrosine Kinase Ubiquitination and DeUbiquitination in Signal Transduction and Receptor Trafficking. Cells (2018) 7(3):22. doi: 10.3390/cells7030022

159. Clague MJ, Urbe S. Endocytosis: the DUB version. Trends Cell Biol (2006) 16:551-9. doi: 10.1016/j.tcb.2006.09.002

160. Lauwers E, Jacob C, Andre B. K63-linked ubiquitin chains as a specific signal for protein sorting into the multivesicular body pathway. J Cell Biol (2009) 185:493-502. doi: 10.1083/jcb.200810114

161. Duncan LM, Piper S, Dodd RB, Saville MK, Sanderson CM, Luzio JP, et al. Lysine-63-linked ubiquitination is required for endolysosomal degradation of class I molecules. EMBO J (2006) 25:1635-45. doi: 10.1038/ sj.emboj.7601056

162. Geetha T, Wooten MW. TrkA Receptor Endolysosomal Degradation is both Ubiquitin and Proteasome Dependent. Traffic (2008) 9:1146-56. doi: 10.1111/j.1600-0854.2008.00751.x

163. Dikic I. Proteasomal and Autophagic Degradation Systems. Annu Rev Biochem (2017) 86:193-224. doi: 10.1146/annurev-biochem-061516-044908

164. Ren X, Hurley JH. VHS domains of ESCRT-0 cooperate in high-avidity binding to polyubiquitinated cargo. EMBO J (2010) 29:1045-54. doi: 10.1038/emboj.2010.6

165. Erpapazoglou Z, Walker O, Haguenauer-Tsapis R. Versatile roles of k63linked ubiquitin chains in trafficking. Cells (2014) 3:1027-88. doi: 10.3390/ cells3041027

166. Sachse M, Strous GJ, Klumperman J. ATPase-deficient hVPS4 impairs formation of internal endosomal vesicles and stabilizes bilayered clathrin coats on endosomal vacuoles. J Cell Sci (2004) 117:1699-708. doi: 10.1242/ jcs.00998

167. Wright MH, Berlin I, Nash PD. Regulation of endocytic sorting by ESCRTDUB-mediated deubiquitination. Cell Biochem Biophys (2011) 60:39-46. doi: 10.1007/s12013-011-9181-9
168. Hassink G, Slotman J, Oorschot V, Van Der Reijden BA, Monteferrario D, Noordermeer SM. et al: Identification of the ubiquitin ligase Triad1 as a regulator of endosomal transport. Biol Open (2012) 1:607-14. doi: 10.1242/ bio. 2012778

169. Govers R, ten Broeke T, van Kerkhof P, Schwartz AL, Strous GJ. Identification of a novel ubiquitin conjugation motif, required for ligandinduced internalization of the growth hormone receptor. EMBO J (1999) 18:28-36. doi: 10.1093/emboj/18.1.28

170. Govers R, van Kerkhof P, Schwartz AL, Strous GJ. Di-leucine-mediated internalization of ligand by a truncated growth hormone receptor is independent of the ubiquitin conjugation system. J Biol Chem (1998) 273:16426-33. doi: 10.1074/jbc.273.26.16426

171. van Kerkhof P, Putters J, Strous GJ. The ubiquitin ligase SCF(betaTrCP) regulates the degradation of the growth hormone receptor. J Biol Chem (2007) 282:20475-83. doi: 10.1074/jbc.M702610200

172. van Kerkhof P, Westgeest M, Hassink G, Strous GJ. SCF(TrCP) acts in endosomal sorting of the GH receptor. Exp Cell Res (2011) 317:1071-82. doi: 10.1016/j.yexcr.2010.12.020

173. Lv K, Jiang J, Donaghy R, Riling CR, Cheng Y, Chandra V, et al. CBL family E3 ubiquitin ligases control JAK2 ubiquitination and stability in hematopoietic stem cells and myeloid malignancies. Genes Dev (2017) 31:1007-23.31:1007-1023. doi: 10.1101/gad.297135.117

174. Frescas D, Pagano M. Deregulated proteolysis by the F-box proteins SKP2 and beta-TrCP: tipping the scales of cancer. Nat Rev Cancer (2008) 8:438-49. doi: $10.1038 / \mathrm{nrc} 2396$

175. Li Y, Suresh Kumar KG, Tang W, Spiegelman VS, Fuchs SY. Negative Regulation of Prolactin Receptor Stability and Signaling Mediated by SCF \{beta\}-TrCP E3 Ubiquitin Ligase. Mol Cell Biol (2004) 24:4038-48. doi: 10.1128/MCB.24.9.4038-4048.2004

176. Kumar KG, Tang W, Ravindranath AK, Clark WA, Croze E, Fuchs SY. SCF (HOS) ubiquitin ligase mediates the ligand-induced down-regulation of the interferon-alpha receptor. $E M B O J$ (2003) 22:5480-90. doi: 10.1093/emboj/ cdg524

177. Meyer L, Deau B, Forejtnikova H, Dumenil D, Margottin-Goguet F, Lacombe $\mathrm{C}$, et al. Beta-Trcp mediates ubiquitination and degradation of the erythropoietin receptor and controls cell proliferation. Blood (2007) 109:5215-22. doi: 10.1182/blood-2006-10-055350

178. da Silva Almeida AC, Hocking HG, Boelens R, Strous GJ, van Rossum AG. betaTrCP interacts with the ubiquitin-dependent endocytosis motif of the GH receptor in an unconventional manner. Biochem J (2013) 453:291-301. doi: 10.1042/BJ20121843

179. da Silva Almeida AC. Understanding the Growth Hormone Receptor- $\beta \operatorname{Tr} C P$ interactions: Molecular Tools for controlling Growth Hormone Sensitivity. Chapter IV, Growth hormone receptor endocytosis and degradation are regulated by phosphorylation of serine 323 in the ubiquitin-dependent endocytosis motiE. Utrecht: Thesis, Utrecht University (2011). Available at: http://dspace.library.uu.nl/handle/1874/350510.

180. Pinna LA. Casein kinase 2: an 'eminence grise' in cellular regulation? Biochim Biophys Acta (1990) 1054, 267-84. doi: 10.1016/0167-4889(90) 90098-X

181. Bian Y, Song C, Cheng K, Dong M, Wang F, Huang J, et al. An enzyme assisted RP-RPLC approach for in-depth analysis of human liver phosphoproteome. J Proteomics (2014) 96:253-62. doi: 10.1016/ j.jprot.2013.11.014

182. Szyszka R, Grankowski N, Felczak K, Shugar D. Halogenated benzimidazoles and benzotriazoles as selective inhibitors of protein kinases CK I and CK II from Saccharomyces cerevisiae and other sources. Biochem Biophys Res Commun (1995) 208:418-24.Biochem Biophys Res Commun 1995, 208:418-424. doi: 10.1006/bbrc.1995.1354

183. Litchfield DW. Protein kinase CK2: structure, regulation and role in cellular decisions of life and death. Biochem J (2003) 369:1-15. doi: 10.1042/ bj20021469

184. Montenarh M. Cellular regulators of protein kinase CK2. Cell Tissue Res (2010) 342:139-46. doi: 10.1007/s00441-010-1068-3

185. Sommercorn J, Mulligan JA, Lozeman FJ, Krebs EG. Activation of casein kinase II in response to insulin and to epidermal growth factor. Proc Natl Acad Sci U S A (1987) 84:8834-8. doi: 10.1073/pnas.84.24.8834 
186. Klarlund JK, Czech MP. Insulin-like growth factor I and insulin rapidly increase casein kinase II activity in BALB/c $3 \mathrm{~T} 3$ fibroblasts. J Biol Chem (1988) 263:15872-5.

187. Van Lint J, Agostinis P, Vandevoorde V, Haegeman G, Fiers W, Merlevede W, et al. Tumor necrosis factor stimulates multiple serine/threonine protein kinases in Swiss 3T3 and L929 cells. Implication of casein kinase-2 and extracellular signal-regulated kinases in the tumor necrosis factor signal transduction pathway. J Biol Chem (1992) 267:25916-21.

188. Kim S, Ham S, Yang K, Kim K. Protein kinase CK2 activation is required for transforming growth factor beta-induced epithelial-mesenchymal transition. Mol Oncol (2018) 12:1811-26. doi: 10.1002/1878-0261.12378

189. Ji H, Wang J, Nika H, Hawke D, Keezer S, Ge Q, et al. EGF-induced ERK activation promotes CK2-mediated disassociation of alpha-Catenin from beta-Catenin and transactivation of beta-Catenin. Mol Cell (2009) 36:54759. doi: 10.1016/j.molcel.2009.09.034

190. Starr R, Willson TA, Viney EM, Murray LJ, Rayner JR, Jenkins BJ, et al. A family of cytokine-inducible inhibitors of signalling. Nature (1997) 387:91721. doi: $10.1038 / 43206$

191. Kile BT, Schulman BA, Alexander WS, Nicola NA, Martin HM, Hilton DJ. The SOCS box: a tale of destruction and degradation. Trends Biochem Sci (2002) 27:235-41. doi: 10.1016/S0968-0004(02)02085-6

192. Yasukawa H, Misawa H, Sakamoto H, Masuhara M, Sasaki A, Wakioka T, et al. The JAK-binding protein JAB inhibits Janus tyrosine kinase activity through binding in the activation loop. EMBO J (1999) 18:1309-20. doi: 10.1093/emboj/18.5.1309

193. Sasaki A, Yasukawa H, Suzuki A, Kamizono S, Syoda T, Kinjyo I, et al. Cytokineinducible SH2 protein-3 (CIS3/SOCS3) inhibits Janus tyrosine kinase by binding through the N-terminal kinase inhibitory region as well as SH2 domain. Genes Cells (1999) 4:339-51. doi: 10.1046/j.1365-2443.1999.00263.x

194. Ram PA, Waxman DJ. SOCS/CIS protein inhibition of growth hormonestimulated STAT5 signaling by multiple mechanisms. J Biol Chem (1999) 274:35553-61. doi: 10.1074/jbc.274.50.35553

195. Landsman T, Waxman DJ. Role of the Cytokine-induced SH2 Domain-containing Protein CIS in Growth Hormone Receptor Internalization. J Biol Chem (2005) 280:37471-80. doi: 10.1074/ jbc.M504125200

196. Leung KC, Doyle N, Ballesteros M, Sjogren K, Watts CK, Low TH, et al. Estrogen inhibits $\mathrm{GH}$ signaling by suppressing GH-induced JAK2 phosphorylation, an effect mediated by SOCS-2. Proc Natl Acad Sci U.S.A. (2003) 100:1016-21. doi: 10.1073/pnas.0337600100

197. Yumet G, Shumate ML, Bryant DP, Lang CH, Cooney RN. Hepatic growth hormone resistance during sepsis is associated with increased suppressors of cytokine signaling expression and impaired growth hormone signaling. Crit Care Med (2006) 34:1420-7. doi: 10.1097/ 01.CCM.0000215113.66070.E0

198. Alexander WS, Starr R, Fenner JE, Scott GL, Handman E, Sprigg NS, et al. SOCS1 is a critical inhibitor of interferon gamma signaling and prevents the potentially fatal neonatal actions of this cytokine. Cell (1999) 98:597-608. doi: 10.1016/S0092-8674(00)80047-1

199. Croker BA, Krebs DL, Zhang JG, Wormald S, Willson TA, Stanley EG, et al. SOCS3 negatively regulates IL-6 signaling in vivo. Nat Immunol (2003) 4:540-5. doi: 10.1038/ni931

200. Starr R, Metcalf D, Elefanty AG, Brysha M, Willson TA, Nicola NA, et al. Liver degeneration and lymphoid deficiencies in mice lacking suppressor of cytokine signaling-1. Proc Natl Acad Sci U.S.A. (1998) 95:14395-9. doi: 10.1073/pnas.95.24.14395

201. Metcalf D, Greenhalgh CJ, Viney E, Willson TA, Starr R, Nicola NA, et al. Gigantism in mice lacking suppressor of cytokine signalling-2. Nature (2000) 405:1069-73. doi: 10.1038/35016611

202. Greenhalgh CJ, Rico-Bautista E, Lorentzon M, Thaus AL, Morgan PO, Willson TA, et al. SOCS2 negatively regulates growth hormone action in vitro and in vivo. J Clin Invest (2005) 115:397-406. doi: 10.1172/JCI22710

203. Kung WW, Ramachandran S, Makukhin N, Bruno E, Ciulli A. Structural insights into substrate recognition by the SOCS2 E3 ubiquitin ligase. Nat Commun (2019) 10:2534. doi: 10.1038/s41467-019-10190-4

204. Rudd MF, Webb EL, Matakidou A, Sellick GS, Williams RD, Bridle H, et al. Variants in the GH-IGF axis confer susceptibility to lung cancer. Genome Res (2006) 16:693-701. doi: 10.1101/gr.5120106
205. Cao G, Lu H, Feng J, Shu J, Zheng D, Hou Y. Lung cancer risk associated with Thr495Pro polymorphism of GHR in Chinese population. Jpn J Clin Oncol (2008) 38:308-16. doi: 10.1093/jjco/hyn007

206. Vincent EE, Elder DJ, Thomas EC, Phillips L, Morgan C, Pawade J, et al. Akt phosphorylation on Thr308 but not on Ser473 correlates with Akt protein kinase activity in human non-small cell lung cancer. Br J Cancer (2011) 104:1755-61. doi: 10.1038/bjc.2011.132

207. Yu Y, Zhao Q, Wang Z, Liu XY. Activated STAT3 correlates with prognosis of non-small cell lung cancer and indicates new anticancer strategies. Cancer Chemother Pharmacol (2015) 75:917-22. doi: 10.1007/s00280-015-2710-2

208. Kamsteeg EJ, Hendriks G, Boone M, Konings IB, Oorschot V, van der Sluijs P, et al. Short-chain ubiquitination mediates the regulated endocytosis of the aquaporin-2 water channel. Proc Natl Acad Sci U S A (2006) 103:18344-9. doi: 10.1073/pnas.0604073103

209. Slotman JA, da Silva Almeida AC, Hassink GC, van de Ven RH, van Kerkhof P, Kuiken HJ, et al. Ubc13 and $\mathrm{COOH}$ terminus of Hsp70-interacting protein (CHIP) are required for growth hormone receptor endocytosis. J Biol Chem (2012) 287:15533-43. doi: 10.1074/jbc.M111.302521

210. Balaji V, Pokrzywa W, Hoppe T. Ubiquitylation Pathways In Insulin Signaling and Organismal Homeostasis. Bioessays (2018) 40:e1700223. doi: 10.1002/bies.201700223

211. Tawo R, Pokrzywa W, Kevei E, Akyuz ME, Balaji V, Adrian S, et al. The Ubiquitin Ligase CHIP Integrates Proteostasis and Aging by Regulation of Insulin Receptor Turnover. Cell (2017) 169:470-482 e413. doi: 10.1016/ j.cell.2017.04.003

212. Sun C, Li HL, Shi ML, Liu QH, Bai J, Zheng JN. Diverse roles of C-terminal Hsp70-interacting protein (CHIP) in tumorigenesis. J Cancer Res Clin Oncol (2014) 140:189-97. doi: 10.1007/s00432-013-1571-5

213. Manning BD, Toker A. AKT/PKB Signaling: Navigating the Network. Cell (2017) 169:381-405. doi: 10.1016/j.cell.2017.04.001

214. Su CH, Wang CY, Lan KH, Li CP, Chao Y, Lin HC, et al. Akt phosphorylation at Thr308 and Ser473 is required for CHIP-mediated ubiquitination of the kinase. Cell Signal (2011) 23:1824-30. doi: 10.1016/ j.cellsig.2011.06.018

215. Dickey CA, Koren J, Zhang YJ, Xu YF, Jinwal UK, Birnbaum MJ, et al. Akt and CHIP coregulate tau degradation through coordinated interactions. Proc Natl Acad Sci U.S.A. (2008) 105:3622-7. doi: 10.1073/pnas.0709180105

216. Cao Z, Li G, Shao Q, Yang G, Zheng L, Zhang T, et al. CHIP: A new modulator of human malignant disorders. Oncotarget (2016) 7:29864-74. doi: 10.18632/oncotarget.8219

217. Kajiro M, Hirota R, Nakajima Y, Kawanowa K, So-ma K, Ito I, et al. The ubiquitin ligase CHIP acts as an upstream regulator of oncogenic pathways. Nat Cell Biol (2009) 11:312-9. doi: 10.1038/ncb1839

218. Wang T, Wang W, Wang Q, Xie R, Landay A, Chen D. The E3 ubiquitin ligase CHIP in normal cell function and in disease conditions. Ann N Y Acad Sci (2020) 1460:3-10. doi: 10.1111/nyas.14206

219. Chung C, Yoo G, Kim T, Lee D, Lee CS, Cha HR, et al. The E3 ubiquitin ligase CHIP selectively regulates mutant epidermal growth factor receptor by ubiquitination and degradation. Biochem Biophys Res Commun (2016) 479:152-8. doi: 10.1016/j.bbrc.2016.07.111

220. D'Ercole AJ, Applewhite GT, Underwood LE. Evidence that somatomedin is synthesized by multiple tissues in the fetus. Dev Biol (1980) 75:315-28. doi: 10.1016/0012-1606(80)90166-9

221. Le Roith D, Bondy C, Yakar S, Liu JL, Butler A. The somatomedin hypothesis: 2001. Endocr Rev (2001) 22:53-74. doi: 10.1210/edrv.22.1.0419

222. Green H, Morikawa M, Nixon T. A dual effector theory of growth-hormone action. Differentiation (1985) 29:195-8. doi: 10.1111/j.1432-0436.1985.tb00316.x

223. Laron Z, Pertzelan A, Mannheimer S. Genetic pituitary dwarfism with high serum concentation of growth hormone-a new inborn error of metabolism? Isr J Med Sci (1966) 2:152-5.

224. Laron Z. Growth Hormone Insensitivity (Laron Syndrome). Rev Endocr Metab Disord (2002) 3:347-55. doi: 10.1023/A:1020905725012

225. Laron Z. Lessons from 50 Years of Study of Laron Syndrome. Endocr Pract 2 (015) 21:1395-402. doi: 10.4158/EP15939.RA

226. Salvatori R, Fan X, Phillips JA,3, Espigares-Martin R, Martin De Lara I, Freeman KL, et al. Three new mutations in the gene for the growth hormone (gh)-releasing hormone receptor in familial isolated gh deficiency type ib. J Clin Endocrinol Metab (2001) 86:273-9. doi: 10.1210/jc.86.1.273 
227. Aguiar-Oliveira MH, Bartke A. Growth Hormone Deficiency: Health and Longevity. Endocr Rev (2019) 40:575-601. doi: 10.1210/er.2018-00216

228. Rowland JE, Lichanska AM, Kerr LM, White M, d'Aniello EM, Maher SL. et al: In vivo analysis of growth hormone receptor signaling domains and their associated transcripts. Mol Cell Biol (2005) 25:66-77. doi: 10.1128/ MCB.25.1.66-77.2005

229. Reddy R, Hope S, Wass J. Acromegaly. BMJ (2010) 341:c4189. doi: 10.1136/ bmj.c4189

230. Fineberg SE, Merimee TJ. Acute metabolic effects of human growth hormone. Diabetes (1974) 23:499-504. doi: 10.2337/diab.23.6.499

231. Rabinowitz D, Klassen GA, Zierler KL. Effect of Human Growth Hormone on Muscle and Adipose Tissue Metabolism in the Forearm of Man. J Clin Invest (1965) 44:51-61. doi: 10.1172/JCI105126

232. Zierler KL, Rabinowitz D. Roles of Insulin and Growth Hormone, Based on Studies of Forearm Metabolism in Man. Med (Baltimore) (1963) 42:385-402. doi: 10.1097/00005792-196311000-00002

233. Sonksen PH, Greenwood FC, Ellis JP, Lowy C, Rutherford A, Nabarro JD. Changes of carbohydrate tolerance in acromegaly with progress of the disease and in response to treatment. J Clin Endocrinol Metab (1967) 27:1418-30. doi: 10.1210/jcem-27-10-1418

234. Wurzburger MI, Prelevic GM, Sonksen PH, Balint-Peric LA, Wheeler M. The effect of recombinant human growth hormone on regulation of growth hormone secretion and blood glucose in insulin-dependent diabetes. J Clin Endocrinol Metab (1993) 77:267-72. doi: 10.1210/jcem.77.1.8325951

235. Clemmons DR, Underwood LE. Nutritional regulation of IGF-I and IGF binding proteins. Annu Rev Nutr (1991) 11:393-412. doi: 10.1146/ annurev.nu.11.070191.002141

236. Sotiropoulos A, Ohanna M, Kedzia C, Menon RK, Kopchick JJ, Kelly PA. et al: Growth hormone promotes skeletal muscle cell fusion independent of insulin-like growth factor 1 up-regulation. PNAS (2006) 103:7315-20. doi: 10.1073/pnas.0510033103

237. Barton-Davis ER, Shoturma DI, Musaro A, Rosenthal N, Sweeney HL. Viral mediated expression of insulin-like growth factor I blocks the aging-related loss of skeletal muscle function. Proc Natl Acad Sci U.S.A. (1998) 95:15603-7. doi: 10.1073/pnas.95.26.15603

238. Moller N, Jorgensen JO. Effects of growth hormone on glucose, lipid, and protein metabolism in human subjects. Endocr Rev (2009) 30:152-77. doi: 10.1210/er.2008-0027

239. Gjedsted J, Gormsen LC, Nielsen S, Schmitz O, Djurhuus CB, Keiding S, et al. Effects of a 3-day fast on regional lipid and glucose metabolism in human skeletal muscle and adipose tissue. Acta Physiol (Oxf) (2007) 191:205-16. doi: 10.1111/j.1748-1716.2007.01740.x

240. Manson JM, Wilmore DW. Positive nitrogen balance with human growth hormone and hypocaloric intravenous feeding. Surgery (1986) 100:188-97.

241. Norrelund H, Moller N, Nair KS, Christiansen JS, Jorgensen JO. Continuation of growth hormone $(\mathrm{GH})$ substitution during fasting in $\mathrm{GH}$-deficient patients decreases urea excretion and conserves protein synthesis. J Clin Endocrinol Metab (2001) 86:3120-9. doi: 10.1210/ jc.86.7.3120

242. Norrelund H, Nair KS, Jorgensen JO, Christiansen JS, Moller N. The proteinretaining effects of growth hormone during fasting involve inhibition of muscle-protein breakdown. Diabetes (2001) 50:96-104. doi: 10.2337/ diabetes.50.1.96

243. Veldhuis JD, Iranmanesh A, Ho KK, Waters MJ, Johnson ML, Lizarralde G. Dual defects in pulsatile growth hormone secretion and clearance subserve the hyposomatotropism of obesity in man. J Clin Endocrinol Metab (1991) 72:51-9. doi: 10.1210/jcem-72-1-51

244. Felig P, Marliss EB, Cahill GFJr. Metabolic response to human growth hormone during prolonged starvation. J Clin Invest (1971) 50:411-21. doi: 10.1172/JCI106508

245. Carter-Su C, King AP, Argetsinger LS, Smit LS, Vanderkuur J, Campbell GS. Signalling pathway of GH. Endocr J (1996) 43 Suppl:S65-70. doi: 10.1507/ endocri.43.Suppl_S65

246. Liu H, Bravata DM, Olkin I, Friedlander A, Liu V, Roberts B, et al. Systematic review: the effects of growth hormone on athletic performance. Ann Intern Med (2008) 148:747-58. doi: 10.7326/0003-4819-148-10-200805200-00215
247. Gibney J, Healy ML, Sonksen PH. The growth hormone/insulin-like growth factor-I axis in exercise and sport. Endocr Rev (2007) 28:603-24. doi: 10.1210/er.2006-0052

248. Birzniece V, Nelson AE, Ho KK. Growth hormone and physical performance. Trends Endocrinol Metab (2011) 22:171-8. doi: 10.1016/ j.tem.2011.02.005

249. Irwig MS, Fleseriu M, Jonklaas J, Tritos NA, Yuen KCJ, Correa R, et al. OffLabel Use and Misuse of Testosterone, Growth Hormone, Thyroid Hormone, and Adrenal Supplements: Risks and Costs of a Growing Problem. Endocr Pract (2020) 26:340-53. doi: 10.4158/PS-2019-0540

250. Colosi P, Wong K, Leong SR, Wood WI. Mutational analysis of the intracellular domain of the human growth hormone receptor. J Biol Chem (1993) 268:12617-23.

251. Goh EL, Pircher TJ, Lobie PE. Growth hormone promotion of tubulin polymerization stabilizes the microtubule network and protects against colchicine-induced apoptosis. Endocrinology (1998) 139:4364-72. doi: 10.1210/endo.139.10.6237

252. Wiedermann CJ, Reinisch N, Braunsteiner H. Stimulation of monocyte chemotaxis by human growth hormone and its deactivation by somatostatin. Blood (1993) 82:954-60. doi: 10.1182/blood.V82.3.954.bloodjournal823954

253. Hattori N. Expression, regulation and biological actions of growth hormone (GH) and ghrelin in the immune system. Growth Horm IGF Res (2009) 19:187-97. doi: 10.1016/j.ghir.2008.12.001

254. Merchav S. The haematopoietic effects of growth hormone and insulin-like growth factor-I. J Pediatr Endocrinol Metab (1998) 11:677-85. doi: 10.1515/ JPEM.1998.11.6.677

255. Masternak MM, Bartke A. Growth hormone, inflammation and aging. Pathobiol Aging Age Relat Dis (2012) 2:1-6. doi: 10.3402/pba.v2i0.17293

256. Yoshizato H, Fujikawa T, Soya H, Tanaka M, Nakashima K. The growth hormone (GH) gene is expressed in the lateral hypothalamus: enhancement by GH-releasing hormone and repression by restraint stress. Endcrinology (1998) 139:2545-51. doi: 10.1210/endo.139.5.6009

257. Wasinski F, Furigo IC, Teixeira PDS, Ramos-Lobo AM, Peroni CN, Bartolini P, et al. Growth Hormone Receptor Deletion Reduces the Density of Axonal Projections from Hypothalamic Arcuate Nucleus Neurons. Neuroscience (2020) 434:136-47. doi: 10.1016/j.neuroscience.2020.03.037

258. Ashpole NM, Sanders JE, Hodges EL, Yan H, Sonntag WE. Growth hormone, insulin-like growth factor-1 and the aging brain. Exp Gerontol (2015) 68:76-81. doi: 10.1016/j.exger.2014.10.002

259. Logan S, Pharaoh GA, Marlin MC, Masser DR, Matsuzaki S, Wronowski B, et al. Insulin-like growth factor receptor signaling regulates working memory, mitochondrial metabolism, and amyloid-beta uptake in astrocytes. Mol Metab (2018) 9:141-55. doi: 10.1016/j.molmet.2018.01.013

260. Sonntag WE, Deak F, Ashpole N, Toth P, Csiszar A, Freeman W, et al. Insulin-like growth factor-1 in CNS and cerebrovascular aging. Front Aging Neurosci (2013) 5:27. doi: 10.3389/fnagi.2013.00027

261. Labandeira-Garcia JL, Costa-Besada MA, Labandeira CM, Villar-Cheda B, Rodriguez-Perez AI. Insulin-Like Growth Factor-1 and Neuroinflammation. Front Aging Neurosci (2017) 9:365. doi: 10.3389/fnagi.2017.00365

262. Quinlan P, Horvath A, Nordlund A, Wallin A, Svensson J. Low serum insulin-like growth factor-I (IGF-I) level is associated with increased risk of vascular dementia. Psychoneuroendocrinology (2017) 86:169-75. doi: 10.1016/j.psyneuen.2017.09.018

263. Colon G, Saccon T, Schneider A, Cavalcante MB, Huffman DM, Berryman $\mathrm{D}$, et al. The enigmatic role of growth hormone in age-related diseases, cognition, and longevity. Geroscience (2019) 41:759-74. doi: 10.1007/s11357019-00096-w

264. Basu A, McFarlane HG, Kopchick JJ. Spatial learning and memory in male mice with altered growth hormone action. Horm Behav (2017) 93:18-30. doi: 10.1016/j.yhbeh.2017.04.001

265. Guevara-Aguirre J, Teran E, Lescano D, Guevara A, Guevara C, Longo V, et al. Growth hormone receptor deficiency in humans associates to obesity, increased body fat percentage, a healthy brain and a coordinated insulin sensitivity. Growth Horm IGF Res (2020) 51:58-64. doi: 10.1016/ j.ghir.2020.02.004

266. Sonntag WE, Csiszar A, deCabo R, Ferrucci L, Ungvari Z. Diverse roles of growth hormone and insulin-like growth factor-1 in mammalian aging: 
progress and controversies. J Gerontol A Biol Sci Med Sci (2012) 67:587-98. doi: 10.1093/gerona/gls115

267. Sun LY, Al-Regaiey K, Masternak MM, Wang J, Bartke A. Local expression of GH and IGF-1 in the hippocampus of GH-deficient long-lived mice. Neurobiol Aging (2005) 26:929-37. doi: 10.1016/j.neurobiolaging. 2004.07.010

268. Lupu F, Terwilliger JD, Lee K, Segre GV, Efstratiadis A. Roles of growth hormone and insulin-like growth factor 1 in mouse postnatal growth. Dev Biol (2001) 229:141-62. doi: 10.1006/dbio.2000.9975

269. Ikeno Y, Bronson RT, Hubbard GB, Lee S, Bartke A. Delayed occurrence of fatal neoplastic diseases in ames dwarf mice: correlation to extended longevity. J Gerontol A Biol Sci Med Sci (2003) 58:291-6. doi: 10.1093/ gerona/58.4.B291

270. Bartke A, Wright JC, Mattison JA, Ingram DK, Miller RA, Roth GS. Extending the lifespan of long-lived mice. Nature (2001) 414:412. doi: $10.1038 / 35106646$

271. Coschigano KT, Holland AN, Riders ME, List EO, Flyvbjerg A, Kopchick JJ. Deletion, but not antagonism, of the mouse growth hormone receptor results in severely decreased body weights, insulin, and insulin-like growth factor I levels and increased life span. Endocrinology (2003) 144:3799-810. doi: 10.1210/en.2003-0374

272. Borg KE, Brown-Borg HM, Bartke A. Assessment of the primary adrenal cortical and pancreatic hormone basal levels in relation to plasma glucose and age in the unstressed Ames dwarf mouse. Proc Soc Exp Biol Med (1995) 210:126-33. doi: 10.3181/00379727-210-43931

273. Flurkey K, Papaconstantinou J, Miller RA, Harrison DE. Lifespan extension and delayed immune and collagen aging in mutant mice with defects in growth hormone production. Proc Natl Acad Sci U.S.A. (2001) 98:6736-41. doi: $10.1073 /$ pnas. 111158898

274. Bartke A, Darcy J. GH and ageing: Pitfalls and new insights. Best Pract Res Clin Endocrinol Metab (2017) 31:113-25. doi: 10.1016/j.beem.2017.02.005

275. Holzenberger M, Dupont J, Ducos B, Leneuve P, Geloen A, Even PC, et al. IGF-1 receptor regulates lifespan and resistance to oxidative stress in mice. Nature (2003) 421:182-7. doi: 10.1038/nature01298

276. Selman C, Lingard S, Choudhury AI, Batterham RL, Claret M, Clements M, et al. Evidence for lifespan extension and delayed age-related biomarkers in insulin receptor substrate 1 null mice. FASEB J (2008) 22:807-18. doi: 10.1096/fj.07-9261com

277. Bartke A. Can Growth Hormone (GH) Accelerate Aging? Evidence from GH-Transgenic Mice. Neuroendocrinology (2003) 78:210-6. doi: 10.1159/ 000073704

278. List EO, Duran-Ortiz S, Kopchick JJ. Effects of tissue-specific GH receptor knockouts in mice. Mol Cell Endocrinol (2020) 515:110919. doi: 10.1016/ j.mce.2020.110919

279. Besson A, Salemi S, Gallati S, Jenal A, Horn R, Mullis PS, et al. Reduced longevity in untreated patients with isolated growth hormone deficiency. J Clin Endocrinol Metab (2003) 88:3664-7. doi: 10.1210/jc.2002-021938

280. Laron Z. Do deficiencies in growth hormone and insulin-like growth factor-1 (IGF-1) shorten or prolong longevity? Mech Ageing Dev (2005) 126:305-7. doi: 10.1016/j.mad.2004.08.02

281. Shevah O, Laron Z. Patients with congenital deficiency of IGF-I seem protected from the development of malignancies: a preliminary report. Growth Horm IGF Res (2007) 17:54-7. doi: 10.1016/ j.ghir.2006.10.007

282. Paolisso G, Giugliano D. Oxidative stress and insulin action: is there a relationship? Diabetologia (1996) 39:357-63. doi: 10.1007/s001250050454

283. Romano AD, Serviddio G, de Matthaeis A, Bellanti F, Vendemiale G. Oxidative stress and aging. J Nephrol (2010) 23 Suppl 15:S29-36. doi: E8657B83-848C-46BE-856E-5377F6875270

284. Brown-Borg HM, Bode AM, Bartke A. Antioxidative mechanisms and plasma growth hormone levels: potential relationship in the aging process. Endocrine (1999) 11:41-8. doi: 10.1385/ENDO:11:1:41

285. Brown-Borg HM, Johnson WT, Rakoczy SG. Expression of oxidative phosphorylation components in mitochondria of long-living Ames dwarf mice. Age (Dordr) (2012) 34:43-57. doi: 10.1007/s11357-011-9212-x

286. Cefalu WT, Wang ZQ, Werbel S, Bell-Farrow A, Crouse JR,3, Hinson WH, et al. Contribution of visceral fat mass to the insulin resistance of aging. Metabolism (1995) 44:954-9. doi: 10.1016/0026-0495(95)90251-1
287. Facchini FS, Hua N, Abbasi F, Reaven GM. Insulin resistance as a predictor of age-related diseases. J Clin Endocrinol Metab (2001) 86:3574-8. doi: 10.1210/jcem.86.8.7763

288. Chen L, Chen Q, Rong P, Wang HY, Chen S. The energy sensing LKB1AMPKalpha1 pathway regulates IGF1 secretion and consequent activation of the IGF1R-PKB pathway in primary hepatocytes. FEBS J (2017) 284:2096109. doi: $10.1111 /$ febs. 14106

289. Chen L, Chen Q, Xie B, Quan C, Sheng Y, Zhu S, et al. Disruption of the AMPK-TBC1D1 nexus increases lipogenic gene expression and causes obesity in mice via promoting IGF1 secretion. Proc Natl Acad Sci U.S.A. (2016) 113:7219-24. doi: 10.1073/pnas.1600581113

290. Russo GL, Russo M, Ungaro P. AMP-activated protein kinase: a target for old drugs against diabetes and cancer. Biochem Pharmacol (2013) 86:339-50. doi: 10.1016/j.bcp.2013.05.023

291. Bartke A. Growth hormone and aging: a challenging controversy. Clin Interv Aging (2008) 3:659-65. doi: 10.2147/CIA.S3697

292. Bartke A, List EO, Kopchick JJ. The somatotropic axis and aging: Benefits of endocrine defects. Growth Horm IGF Res (2016) 27:41-5. doi: 10.1016/ j.ghir.2016.02.002

293. Bartke A, Sun LY, Longo V. Somatotropic signaling: trade-offs between growth, reproductive development, and longevity. Physiol Rev (2013) 93:571-98. doi: 10.1152/physrev.00006.2012

294. Basu R, Wu S, Kopchick JJ. Targeting growth hormone receptor in human melanoma cells attenuates tumor progression and epithelial mesenchymal transition via suppression of multiple oncogenic pathways. Oncotarget (2017) 8:21579-98. doi: 10.18632/oncotarget.15375

295. Dagnaes-Hansen F, Duan H, Rasmussen LM, Friend KE, Flyvbjerg A. Growth hormone receptor antagonist administration inhibits growth of human colorectal carcinoma in nude mice. Anticancer Res (2004) 24:3735-42.

296. Farabaugh SM, Boone DN, Lee AV. Role of IGF1R in Breast Cancer Subtypes, Stemness, and Lineage Differentiation. Front Endocrinol (Lausanne) (2015) 6:59. doi: 10.3389/fendo.2015.00059

297. van Garderen E, van der Poel HJA, Swennenhuis JF, Wissink EHJ, Rutteman GR, Hellmen E, et al. Expression and molecular characterization of the growth hormone receptor in canine mammary tissue and mammary tumors. Endocrinology (1999) 140:5907-14. doi: 10.1210/endo.140.12.7189

298. Hoppe R, Fan P, Buttner F, Winter S, Tyagi AK, Cunliffe H, et al. Profiles of miRNAs matched to biology in aromatase inhibitor resistant breast cancer. Oncotarget (2016) 7:71235-54. doi: 10.18632/oncotarget.12103

299. Jung EJ, Santarpia L, Kim J, Esteva FJ, Moretti E, Buzdar AU, et al. Plasma microRNA 210 levels correlate with sensitivity to trastuzumab and tumor presence in breast cancer patients. Cancer (2012) 118:2603-14. doi: 10.1002/ cncr.26565

300. Chesnokova V, Zonis S, Zhou C, Recouvreux MV, Ben-Shlomo A, Araki T, et al. Growth hormone is permissive for neoplastic colon growth. Proc Natl Acad Sci U.S.A. (2016) 113:E3250-3259. doi: 10.1073/pnas.1600561113

301. Mukhina S, Mertani HC, Guo K, Lee KO, Gluckman PD, Lobie PE. Phenotypic conversion of human mammary carcinoma cells by autocrine human growth hormone. Proc Natl Acad Sci U.S.A. (2004) 101:15166-71. doi: 10.1073/pnas.0405881101

302. Waters MJ, Conway-Campbell BL. The oncogenic potential of autocrine human growth hormone in breast cancer. Proc Natl Acad Sci U.S.A. (2004) 101:14992-3. doi: 10.1073/pnas.0406396101

303. Zhu T, Starling-Emerald B, Zhang X, Lee KO, Gluckman PD, Mertani HC, et al. Oncogenic transformation of human mammary epithelial cells by autocrine human growth hormone. Cancer Res (2005) 65:317-24.

304. Zhang X, Mehta RG, Lantvit DD, Coschigano KT, Kopchick JJ, Green JE, et al. Inhibition of estrogen-independent mammary carcinogenesis by disruption of growth hormone signaling. Carcinogenesis (2007) 28:143-50. doi: 10.1093/carcin/bgl138

305. Wang Z, Luque RM, Kineman RD, Ray VH, Christov KT, Lantvit DD, et al. Disruption of growth hormone signaling retards prostate carcinogenesis in the Probasin/TAg rat. Endocrinology (2008) 149:1366-76. doi: 10.1210/ en.2007-1410

306. Shen Q, Lantvit DD, Lin Q, Li Y, Christov K, Wang Z, et al. Advanced rat mammary cancers are growth hormone dependent. Endocrinology (2007) 148:4536-44. doi: 10.1210/en.2007-0513 
307. Raccurt M, Lobie PE, Moudilou E, Garcia-Caballero T, Frappart L, Morel G, et al. High stromal and epithelial human gh gene expression is associated with proliferative disorders of the mammary gland. J Endocrinol (2002) 175:307-18.Endocrinol 2002, 175:307-318. doi: 10.1677/joe.0.1750307

308. Zhu X, Li Y, Xu G, Fu C. Growth hormone receptor (GHR) promotes breast cancer progression via the BRAF/MEK/ERK signaling pathway. FEBS Open Bio (2020), 10(6):1013-20. doi: 10.1002/2211-5463.12816

309. Perry JK, Wu ZS, Mertani HC, Zhu T, Lobie PE. Tumour-Derived Human Growth Hormone As a Therapeutic Target in Oncology. Trends Endocrinol Metab (2017) 28(8):587-96. doi: 10.1016/j.tem.2017.05.003

310. Jensen BW, Gamborg M, Gogenur I, Renehan AG, Sorensen TIA, Baker JL. Childhood body mass index and height in relation to site-specific risks of colorectal cancers in adult life. Eur J Epidemiol (2017) 32:1097-106. doi: 10.1007/s10654-017-0289-0

311. Meyle KD, Gamborg M, Sorensen TIA, Baker JL. Childhood Body Size and the Risk of Malignant Melanoma in Adulthood. Am J Epidemiol (2017) 185:673-80. doi: 10.1093/aje/kww128

312. Perez-Cornago A, Appleby PN, Pischon T, Tsilidis KK, Tjonneland A, Olsen A, et al. Tall height and obesity are associated with an increased risk of aggressive prostate cancer: results from the EPIC cohort study. BMC Med (2017) 15:115. doi: 10.1186/s12916-017-0876-7

313. Sohn K. Now, the Taller Die Earlier: The Curse of Cancer. J Gerontol A Biol Sci Med Sci (2016) 71:713-9. doi: 10.1093/gerona/glv065

314. Subramani R, Nandy SB, Pedroza DA, Lakshmanaswamy R. Role of Growth Hormone in Breast Cancer. Endocrinology (2017) 158:1543-55. doi: 10.1210/ en.2016-1928

315. Brittain AL, Basu R, Qian Y, Kopchick JJ. Growth Hormone and the Epithelial-to-Mesenchymal Transition. J Clin Endocrinol Metab (2017) 102:3662-73. doi: 10.1210/jc.2017-01000

316. Hirakawa T, Yashiro M, Doi Y, Kinoshita H, Morisaki T, Fukuoka T, et al. Pancreatic Fibroblasts Stimulate the Motility of Pancreatic Cancer Cells through IGF1/IGF1R Signaling under Hypoxia. PloS One (2016) 11: e0159912. doi: 10.1371/journal.pone.0159912

317. Lantinga-van Leeuwen IS, Timmermans-Sprang EA, Mol JA. Cloning and characterization of the 5'-flanking region of the canine growth hormone gene. Mol Cell Endocrinol (2002) 197:133-41. doi: 10.1016/S0303-7207(02)00257-5

318. Lamouille S, Xu J, Derynck R. Molecular mechanisms of epithelialmesenchymal transition. Nat Rev Mol Cell Biol (2014) 15:178-96. doi: $10.1038 / \mathrm{nrm} 3758$

319. Kopchick JJ, List EO, Kelder B, Gosney ES, Berryman DE. Evaluation of growth hormone $(\mathrm{GH})$ action in mice: discovery of GH receptor antagonists and clinical indications. Mol Cell Endocrinol (2014) 386:34-45.antagonists and clinical indications. Mol Cell Endocrinol 2014, 386:34-45. doi: 10.1016/ j.mce.2013.09.004

320. Lee SK, Hwang JH, Choi KY. Interaction of the Wnt/beta-catenin and RASERK pathways involving co-stabilization of both beta-catenin and RAS plays important roles in the colorectal tumorigenesis. Adv Biol Regul (2018) 68:4654. doi: 10.1016/j.jbior.2018.01.001

321. Phesse TJ, Buchert M, Stuart E, Flanagan DJ, Faux M, Afshar-Sterle S, et al. Partial inhibition of gp130-Jak-Stat3 signaling prevents Wnt-beta-cateninmediated intestinal tumor growth and regeneration. Sci Signal (2014) 7:ra92. doi: 10.1126/scisignal.2005411

322. Basu R, Kopchick JJ. The effects of growth hormone on therapy resistance in cancer. Cancer Drug Resistance (2019) 2:827-46. doi: 10.20517/ cdr.2019.27

323. Basu R, Kulkarni P, Qian Y, Walsh C, Arora P, Davis E, et al. Growth Hormone Upregulates Melanocyte-Inducing Transcription Factor Expression and Activity via JAK2-STAT5 and SRC Signaling in GH Receptor-Positive Human Melanoma. Cancers (Basel) (2019) 11:1352. doi: $10.3390 /$ cancers 11091352

324. Dusterhoft S, Babendreyer A, Giese AA, Flasshove C, Ludwig A. Status update on iRhom and ADAM17: It's still complicated. Biochim Biophys Acta Mol Cell Res (2019) 1866:1567-83. doi: 10.1016/j.bbamcr.2019.06.017

325. Zhang Y, Li Y, Yang X, Wang J, Wang R, Qian X, et al. Uev1A-Ubc13 catalyzes K63-linked ubiquitination of RHBDF2 to promote TACE maturation. Cell Signal (2018) 42:155-64. doi: 10.1016/j.cellsig.2017.10.013

326. Alves dos Santos CM, ten Broeke T, Strous GJ. Growth hormone receptor ubiquitination, endocytosis, and degradation are independent of signal transduction via Janus kinase 2. J Biol Chem (2001) 276:32635-41. doi: 10.1074/jbc.M103583200

327. Matsuda T, Feng J, Witthuhn BA, Sekine Y, Ihle JN. Determination of the transphosphorylation sites of Jak2 kinase. Biochem Biophys Res Commun (2004) 325:586-94. doi: 10.1016/j.bbrc.2004.10.071

328. Li G, Zhou L, Zhang C, Shi Y, Dong D, Bai M, et al. Insulin-Like Growth Factor 1 Regulates Acute Inflammatory Lung Injury Mediated by Influenza Virus Infection. Front Microbiol (2019) 10:2541. doi: 10.3389/fmicb.2019.02541

329. Behrens EM, Koretzky GA. Review: Cytokine Storm Syndrome: Looking Toward the Precision Medicine Era. Arthritis Rheumatol (2017) 69:1135-43. doi: 10.1002/art.40071

330. Graham JB, Canniff NP, Hebert DN. TPR-containing proteins control protein organization and homeostasis for the endoplasmic reticulum. Crit Rev Biochem Mol Biol (2019) 54:103-18. doi: 10.1080/10409238.2019.1590305

331. van Kerkhof P, Strous GJ. The ubiquitin-proteasome pathway regulates lysosomal degradation of the growth hormone receptor and its ligand. Biochem Soc Trans (2001) 29:488-93. doi: 10.1042/bst0290488

332. Ji S, Guan R, Frank SJ, Messina JL. Insulin inhibits growth hormone signaling via the growth hormone receptor/JAK2/STAT5B pathway. J Biol Chem (1999) 274:13434-42. doi: 10.1074/jbc.274.19.13434

333. Bergan-Roller HE, Sheridan MA. The growth hormone signaling system: Insights into coordinating the anabolic and catabolic actions of growth hormone. Gen Comp Endocrinol (2017) 258:119-33. doi: 10.1016/j.ygcen.2017.07.028

334. Bergan-Roller HE, Ickstadt AT, Kittilson JD, Sheridan MA. Insulin and insulin-like growth factor-1 modulate the lipolytic action of growth hormone by altering signal pathway linkages. Gen Comp Endocrinol (2017) 248:40-8. doi: 10.1016/j.ygcen.2017.04.005

335. Leung KC, Waters MJ, Markus I, Baumbach WR, Ho KK. Insulin and insulin-like growth factor-I acutely inhibit surface translocation of growth hormone receptors in osteoblasts: a novel mechanism of growth hormone receptor regulation. Proc Natl Acad Sci U S A (1997) 94:11381-6.94:1138111386. doi: $10.1073 /$ pnas.94.21.11381

336. Leung KC, Johannsson G, Leong GM, Ho KK. Estrogen regulation of growth hormone action. Endocr Rev (2004) 25:693-721. doi: 10.1210/er.2003-0035

337. Wang P, Li N, Li JS, Li WQ. The role of endotoxin, TNF-alpha, and IL-6 in inducing the state of growth hormone insensitivity. World J Gastroenterol (2002) 8:531-6. doi: 10.3748/wjg.v8.i3.531

338. Zheng Y, Qin H, Frank SJ, Deng L, Litchfield DW, Tefferi A, et al. A CK2dependent mechanism for activation of the JAK-STAT signaling pathway. Blood (2011) 118:156-66. doi: 10.1182/blood-2010-01-266320

339. De Luca F. Impaired growth plate chondrogenesis in children with chronic illnesses. Pediatr Res (2006) 59:625-9. doi: 10.1203/01.pdr.0000214966.60416.1b

340. Gevers EF, Hannah MJ, Waters MJ, Robinson IC. Regulation of rapid signal transducer and activator of transcription-5 phosphorylation in the resting cells of the growth plate and in the liver by growth hormone and feeding. Endocrinology (2009) 150:3627-36. doi: 10.1210/en.2008-0985

341. Ahmed SF, Farquharson C. The effect of GH and IGF1 on linear growth and skeletal development and their modulation by SOCS proteins. $J$ Endocrinol (2010) 206:249-59. doi: 10.1677/JOE-10-0045

342. Zhang J-G, Farley A, Nicholson SE, Willson TA, Zugano LM, Simpson RJ, et al. The conserved SOCS box motif in suppressors of cytokines signalling binds to elongins $\mathrm{B}$ and $\mathrm{C}$ and may couple bound proteins to proteasomal degradation. Proc Nat Acad Sci USA (1999) 96:2071-6.

343. Alves dos Santos CM, van Kerkhof P, Strous GJ. The signal transduction of the growth hormone receptor is regulated by the ubiquitin/proteasome system and continues after endocytosis. J Biol Chem (2001) 276:10839-46. doi: 10.1074/jbc.M003635200

344. Chhabra Y, Nelson CN, Plescher M, Barclay JL, Smith AG, Andrikopoulos S, et al. Loss of growth hormone-mediated signal transducer and activator of transcription 5 (STAT5) signaling in mice results in insulin sensitivity with obesity. FASEB J (2019) 33:6412-30. doi: 10.1096/fj.201802328R

345. Derr MA, Fang P, Sinha SK, Ten S, Hwa V, Rosenfeld RG. A novel Y332C missense mutation in the intracellular domain of the human growth hormone receptor does not alter STAT5b signaling: redundancy of GHR intracellular tyrosines involved in STAT5b signaling. Horm Res Paediatr (2011) 75:187-99. doi: 10.1159/000320461

346. Glad CA, Barbosa EJ, Filipsson Nystrom H, Carlsson LM, Nilsson S, Nilsson AG. et al: SNPs within the GH-signaling pathway are associated with the 
early IGF1 response to GH replacement therapy in GHD adults. Eur J Endocrinol (2014) 170:101-7. doi: 10.1530/EJE-13-0685

347. Chhabra Y, Waters MJ, Brooks AJ. Role of the growth hormone-IGF-1 axis in cancer. Expert Rev Endocrinol Metab (2011) 6:71-84. doi: 10.1586/eem.10.73

348. Saxton RA, Sabatini DM. mTOR Signaling in Growth, Metabolism, and Disease. Cell (2017) 168:960-76. doi: 10.1016/j.cell.2017.02.004

Conflict of Interest: GS was employed by BIMINI Biotech. B.V., Leiden.

The remaining authors declare that the research was conducted in the absence of any commercial or financial relationships that could be construed as a potential conflict of interest.
Citation: Strous GJ, Almeida ADS, Putters J, Schantl J, Sedek M, Slotman JA, Nespital T, Hassink GC and Mol JA (2020) Growth Hormone Receptor Regulation in Cancer and Chronic Diseases.

Front. Endocrinol. 11:597573. doi: 10.3389/fendo.2020.597573

Copyright (c) 2020 Strous, Almeida, Putters, Schantl, Sedek, Slotman, Nespital, Hassink and Mol. This is an open-access article distributed under the terms of the Creative Commons Attribution License (CC BY). The use, distribution or reproduction in other forums is permitted, provided the original author(s) and the copyright owner(s) are credited and that the original publication in this journal is cited, in accordance with accepted academic practice. No use, distribution or reproduction is permitted which does not comply with these terms. 